\title{
Experimental assessment of the sensitivity of an estuarine phytoplankton fall bloom to acidification and warming
}

\author{
Robin Bénard ${ }^{1}$, Maurice Levasseur ${ }^{1}$, Michael Scarratt ${ }^{2}$, Marie-Amélie Blais ${ }^{1}$, Alfonso Mucci ${ }^{3}$, Gustavo Ferreyra ${ }^{4,5}$, \\ Michel Starr $^{2}$, Michel Gosselin ${ }^{4}$, Jean-Éric Tremblay ${ }^{1}$, and Martine Lizotte ${ }^{1}$ \\ ${ }^{1}$ Département de biologie, Université Laval, 1045 avenue de la Médecine, Québec, Québec G1V 0A6, Canada \\ ${ }^{2}$ Fisheries and Oceans Canada, Maurice Lamontagne Institute, P.O. Box 1000, Mont-Joli, Québec G5H 3Z4, Canada \\ ${ }^{3}$ Department of Earth and Planetary Sciences, McGill University, 3450 University Street, \\ Montréal, Québec H3A 2A7, Canada \\ ${ }^{4}$ Institut des sciences de la mer de Rimouski (ISMER), Université du Québec à Rimouski, \\ 310 allée des Ursulines, Rimouski, Québec G5L 3A1, Canada \\ ${ }^{5}$ Centro Austral de Investigaciones Científicas (CADIC), Consejo Nacional de Investigaciones Científicas y Técnicas, \\ Bernardo Houssay 200, 9410 Ushuaia, Tierra del Fuego, Argentina
}

Correspondence: Robin Bénard (robin.benard.1@ulaval.ca)

Received: 17 January 2018 - Discussion started: 7 February 2018

Revised: 30 May 2018 - Accepted: 9 July 2018 - Published: 17 August 2018

\begin{abstract}
We investigated the combined effect of ocean acidification and warming on the dynamics of the phytoplankton fall bloom in the Lower St. Lawrence Estuary (LSLE), Canada. Twelve $2600 \mathrm{~L}$ mesocosms were set to initially cover a wide range of $\mathrm{pH}_{\mathrm{T}}$ ( $\mathrm{pH}$ on the total proton scale) from 8.0 to 7.2 corresponding to a range of $p \mathrm{CO}_{2}$ from 440 to $2900 \mu \mathrm{atm}$, and two temperatures (in situ and $+5^{\circ} \mathrm{C}$ ). The 13-day experiment captured the development and decline of a nanophytoplankton bloom dominated by the chainforming diatom Skeletonema costatum. During the development phase of the bloom, increasing $p \mathrm{CO}_{2}$ influenced neither the magnitude nor the net growth rate of the nanophytoplankton bloom, whereas increasing the temperature by $5^{\circ} \mathrm{C}$ stimulated the chlorophyll $a(\mathrm{Chl} a)$ growth rate and maximal particulate primary production $\left(P_{\mathrm{P}}\right)$ by $76 \%$ and $63 \%$, respectively. During the declining phase of the bloom, warming accelerated the loss of diatom cells, paralleled by a gradual decrease in the abundance of photosynthetic picoeukaryotes and a bloom of picocyanobacteria. Increasing $p \mathrm{CO}_{2}$ and warming did not influence the abundance of picoeukaryotes, while picocyanobacteria abundance was reduced by the increase in $p \mathrm{CO}_{2}$ when combined with warming in the latter phase of the experiment. Over the full duration of the experiment, the time-integrated net primary production was not significantly affected by the $p \mathrm{CO}_{2}$ treatments or warming.
\end{abstract}

Overall, our results suggest that warming, rather than acidification, is more likely to alter phytoplankton autumnal bloom development in the LSLE in the decades to come. Future studies examining a broader gradient of temperatures should be conducted over a larger seasonal window in order to better constrain the potential effect of warming on the development of blooms in the LSLE and its impact on the fate of primary production.

\section{Introduction}

Anthropogenic emissions have increased atmospheric carbon dioxide $\left(\mathrm{CO}_{2}\right)$ concentrations from their pre-industrial value of $280 \mathrm{ppm}$ to $412 \mathrm{ppm}$ in 2017 , and concentrations of $850-1370 \mathrm{ppm}$ are expected by the end of the century under business-as-usual scenario RCP 8.5 (IPCC, 2013). The global ocean has already absorbed about $28 \%$ of these anthropogenic $\mathrm{CO}_{2}$ emissions (Le Quéré et al., 2015), leading to a global $\mathrm{pH}$ decrease of 0.11 units (Gattuso et al., 2015), a phenomenon known as ocean acidification (OA). The surface ocean $\mathrm{pH}$ is expected to decrease by an additional $0.3-$ 0.4 units under the RCP 8.5 scenario by 2100 , and as much as 0.8 units by 2300 (Caldeira and Wickett, 2005; Doney et al., 2009; Feely et al., 2009). The accumulation of anthro- 
pogenic $\mathrm{CO}_{2}$ in the atmosphere also results in an increase in the Earth's heat content that is primarily absorbed by the ocean (Wijffels et al., 2016), leading to an expected rise of sea surface temperatures of 3 to $5^{\circ} \mathrm{C}$ by 2100 (IPCC, 2013). Whereas the effect of increasing atmospheric $\mathrm{CO}_{2}$ partial pressures $\left(p \mathrm{CO}_{2}\right)$ on ocean chemistry is relatively well documented, the potential impacts of OA on marine organisms and how their response to OA will be modulated by the concurrent warming of the ocean surface waters are still the subject of much debate (Boyd and Hutchins, 2012; Gattuso et al., 2013).

Over the last decade, there has been increasing interest in the potential effects of OA on marine organisms (Kroeker et al., 2013). The first experiments were primarily conducted on single phytoplankton species (reviewed in Riebesell and Tortell, 2011), but subsequent mesocosm experiments highlighted the impact of OA on the structure and productivity of complex plankton assemblages (Riebesell et al., 2007, 2013). Due to their widely different initial and experimental conditions, these ecosystem-level experiments generated contrasting results (Schulz et al., 2017), but some general patterns nevertheless emerged. For example, diatoms generally benefit from higher $p \mathrm{CO}_{2}$ through stimulated photosynthesis and growth rates since the increase in $\mathrm{CO}_{2}$ concentrations compensates for the low affinity of RuBisCO towards $\mathrm{CO}_{2}$ (Giordano et al., 2005; Gao and Campbell, 2014). Although most phytoplankton species have developed carbon concentration mechanisms (CCMs) to compensate for the low affinity of RuBisCO towards $\mathrm{CO}_{2}$, CCM efficiencies differ between taxa, rendering predictions of the impact of a $\mathrm{CO}_{2}$ rise on the downregulation of CCM rather difficult (Raven et al., 2014). For example, some studies unexpectedly reported no significant or very modest stimulation of primary production under elevated $\mathrm{CO}_{2}$ concentrations (Engel et al., 2005; Eberlein et al., 2017). OA can ultimately affect the structure of phytoplankton assemblages. Small cells such as photosynthetic picoeukaryotes can benefit directly from an increase in $p \mathrm{CO}_{2}$ as $\mathrm{CO}_{2}$ can passively diffuse through their boundary layer (Beardall et al., 2014), and the smallest organisms within this group could benefit most from the increase (Brussaard et al., 2013). Accordingly, OA experiments have typically favoured smaller phytoplankton cells (Yoshimura et al., 2010; Brussaard et al., 2013; Morán et al., 2015), although the proliferation of larger cells has also been reported (Tortell et al., 2002). Hence, generic predictions of phytoplankton community responses to $\mathrm{OA}$ are challenging.

Few recent studies have investigated the combined effects of $\mathrm{OA}$ and warming on natural phytoplankton assemblages (Hare et al., 2007; Feng et al., 2009; Maugendre et al., 2015; Paul et al., 2015, 2016). Laboratory experiments have shown that $\mathrm{OA}$ and warming could together increase photosynthetic rates, but at the expense of species richness, the reduction of diversity predominantly imputable to warming (Tatters et al., 2013). Results of an experiment conducted with a natural planktonic community from the Mediterranean Sea showed no effect of a combined warming and decrease in $\mathrm{pH}$ on primary production, but higher picocyanobacteria abundances were observed in the warmer treatment (Maugendre et al., 2015). Shipboard microcosm incubations conducted in the northern South China Sea displayed higher phytoplankton biomass, daytime primary productivity, and dark community respiration under warmer conditions, but these positive responses were cancelled at low pH (Gao et al., 2017). In contrast, a mesocosm experiment carried out with a fall planktonic community from the western Baltic Sea led to a decrease in phytoplankton biomass under warming, but combined warming and increased $p \mathrm{CO}_{2}$ led to an increase in biomass (Sommer et al., 2015). Results from experiments where the impacts of $p \mathrm{CO}_{2}$ and temperature are investigated individually may be misleading as multiple stressors can interact antagonistically or synergistically, sometimes in a nonlinear, unpredictable fashion (Todgham and Stillman, 2013; Boyd et al., 2015; Riebesell and Gattuso, 2015; Gunderson et al., 2016).

The Lower St. Lawrence Estuary (LSLE) is a large $\left(9350 \mathrm{~km}^{2}\right)$ segment of the greater St. Lawrence Estuary (d'Anglejan, 1990). From June to September, the LSLE is characterized by a dynamic succession in the phytoplankton community, mostly driven by changes in light and nutrient availability through variations in the intensity of vertical mixing (Levasseur et al., 1984). The spring and fall blooms are mostly comprised of diatoms, with simultaneous nitrate and silicic acid exhaustion ultimately limiting primary production (Levasseur and Therriault, 1987; Roy et al., 1996). How OA and warming may affect these blooms and primary production has never been investigated in the LSLE. The OA problem is complex in estuarine and coastal waters where freshwater runoff, tidal mixing, and high biological activity contribute to variations in $p \mathrm{CO}_{2}$ and $\mathrm{pH}$ on different timescales (Duarte et al., 2013). The surface mixed-layer $p \mathrm{CO}_{2}$ in the LSLE varies spatially from 139 to $548 \mu \mathrm{atm}$ and is strongly modulated by biological productivity (Dinauer and Mucci, 2017). Surface $\mathrm{pH}_{\mathrm{T}}$ has been shown to vary from 7.85 to 7.93 in a single tidal cycle in the LSLE, nearly as much as the world's oceans have experienced in response to anthropogenic $\mathrm{CO}_{2}$ uptake over the last century (Caldeira and Wickett, 2005; Mucci et al., 2018).

The main objective of this study was to experimentally assess the sensitivity of the LSLE phytoplankton fall assemblage to a large $p \mathrm{CO}_{2}$ gradient at two temperatures (in situ and $+5^{\circ} \mathrm{C}$ ). Whether lower trophic-level microorganisms thriving in a highly variable environment will show higher resistance or resilience to future anthropogenic forcings is still a matter of speculation. 


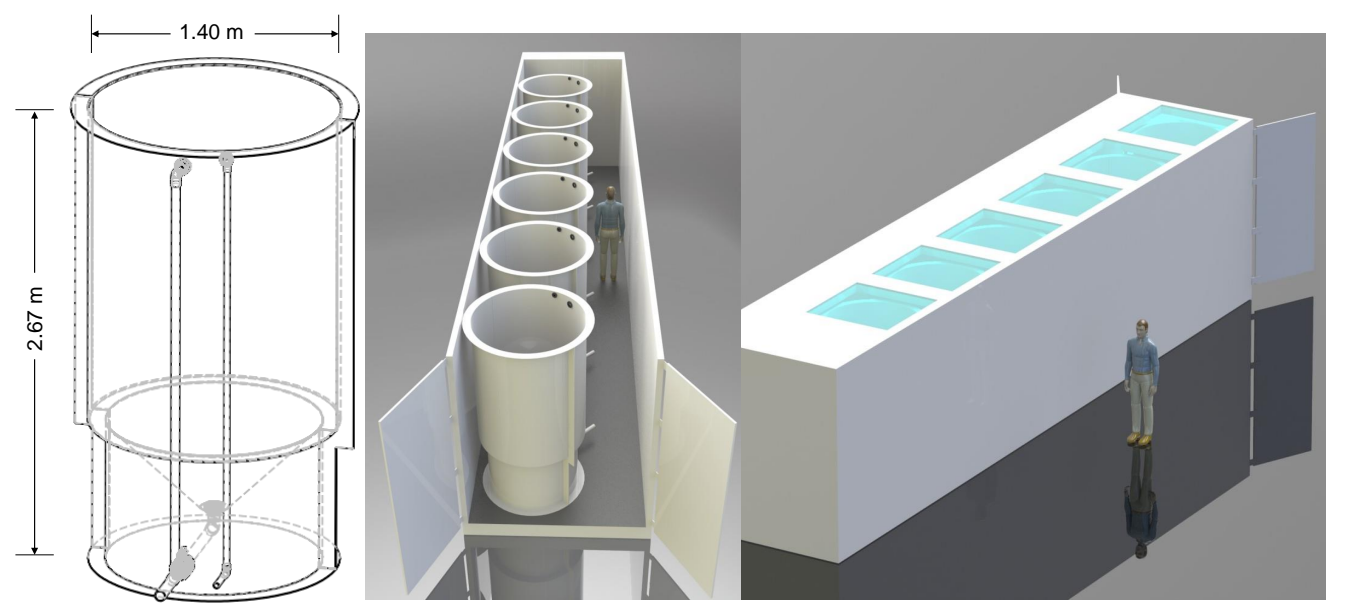

Figure 1. Schematic drawing including mesocosm dimensions and placement within the containers (Aquabiotech Inc., Québec, Canada). The whole setup includes a second container holding six more mesocosms not depicted here.

\section{Material and methods}

\subsection{Mesocosm setup}

The mesocosm system consists of two thermostated fullsize ship containers each holding six $2600 \mathrm{~L}$ mesocosms (Aquabiotech Inc., Québec, Canada). The mesocosms are cylindrical $(2.67 \mathrm{~m} \times 1.40 \mathrm{~m})$ with a cone-shaped bottom within which mixing is achieved using a propeller fixed near the top (Fig. 1). The mesocosms exhibit opaque walls and all lie on the same plane level so as not to shade each other. Light penetrates the mesocosms only through a sealed Plexiglas circular cover at their uppermost part. The cover allows the transmission of $90 \%$ of photosynthetically active radiation (PAR; $400-700 \mathrm{~nm}), 85-90 \%$ of UVA (315-400 nm), and $50-85 \%$ of solar UVB $(280-315 \mathrm{~nm})$. The mesocosms are equipped with individual, independent temperature probes (AQBT-Temperature sensor, accuracy $\pm 0.2^{\circ} \mathrm{C}$ ). Temperature in the mesocosms was measured every 15 min during the experiment, and the control system triggered either a resistance heater (Process Technology TTA1.8215) located near the middle of the mesocosm or a pump-activated glycol refrigeration system to maintain the set temperature. The $\mathrm{pH}$ in each mesocosm was monitored every 15 min using $\mathrm{Hach}^{\circledR}$ PD1P1 probes ( $\pm 0.02 \mathrm{pH}$ units) connected to $\mathrm{Hach}^{\circledR} \mathrm{SC} 200$ controllers, and positive deviations from the target values activated peristaltic pumps linked to a reservoir of artificial seawater equilibrated with pure $\mathrm{CO}_{2}$ prior to the onset of the experiment. This system maintained the $\mathrm{pH}$ of the seawater in the mesocosms within $\pm 0.02 \mathrm{pH}$ units of the targeted values by lowering the $\mathrm{pH}$ during autotrophic growth, but could not increase the $\mathrm{pH}$ during bloom senescence when the $p \mathrm{CO}_{2}$ rose and $\mathrm{pH}$ decreased.

\subsection{Setting}

The water was collected at $5 \mathrm{~m}$ depth near Rimouski harbour $\left(48^{\circ} 28^{\prime} 39.9^{\prime \prime} \mathrm{N}, 68^{\circ} 31^{\prime} 03.0^{\prime \prime} \mathrm{W}\right)$ on 27 September 2014 (indicated as day -5 hereafter), and the experiment lasted until 15 October 2014 (day 13). In situ conditions were salinity $=26.52$, temperature $=10^{\circ} \mathrm{C}$, nitrate $\left(\mathrm{NO}_{3}^{-}\right)=12.8 \pm$ $0.6 \mu \mathrm{mol} \mathrm{L}^{-1}$, silicic acid $\left(\mathrm{Si}(\mathrm{OH})_{4}\right)=16 \pm 2 \mu \mathrm{mol} \mathrm{L}^{-1}$, and soluble reactive phosphate $(\mathrm{SRP})=1.4 \pm 0.3 \mu \mathrm{mol} \mathrm{L}^{-1}$. On day -5 , the water was filtered through a $250 \mu \mathrm{m}$ mesh while simultaneously filling the 12 mesocosm tanks by gravity with a custom-made "octopus" tubing system. The initial $p \mathrm{CO}_{2}$ was $623 \pm 7 \mu$ atm and the in situ temperature of $10^{\circ} \mathrm{C}$ was maintained in the 12 mesocosms for the first $24 \mathrm{~h}$ (day -4). After that period, the six mesocosms in one container were maintained at $10^{\circ} \mathrm{C}$, while temperature was gradually increased to $15^{\circ} \mathrm{C}$ over day -3 in the six mesocosms of the other container. To avoid subjecting the planktonic communities to excessive stress due to sudden changes in temperature and $\mathrm{pH}$ while setting the experiment, the mesocosms were left to acclimatize on day -2 before acidification was carried out over day -1 . One mesocosm from each temperaturecontrolled container was not $\mathrm{pH}$-controlled to assess the community response to the freely fluctuating $\mathrm{pH}$. These two mesocosms were labelled "Drifters" as the initial in situ $\mathrm{pH}$ was allowed to fluctuate over time with the development of the phytoplankton bloom. The other mesocosms were set to cover a range of $\mathrm{pH}_{\mathrm{T}}$ of $\sim 8.0$ to $\sim 7.2$ corresponding to a $p \mathrm{CO}_{2}$ gradient of $\sim 440$ to $\sim 2900 \mu \mathrm{atm}$ after acidification was carried out. To attain initial targeted $\mathrm{pH}, \mathrm{CO}_{2}-$ saturated artificial seawater was added to the mesocosms that needed a pH lowering, while mesocosms M2 (8.0), M4 (7.8), M6 (Drifter), M9 (8.0), M11 (Drifter), and M12 (7.8) were openly mixed to allow the degassing of the supersaturated $\mathrm{CO}_{2}$. Once the mesocosms had reached their target $\mathrm{pH}$, the 


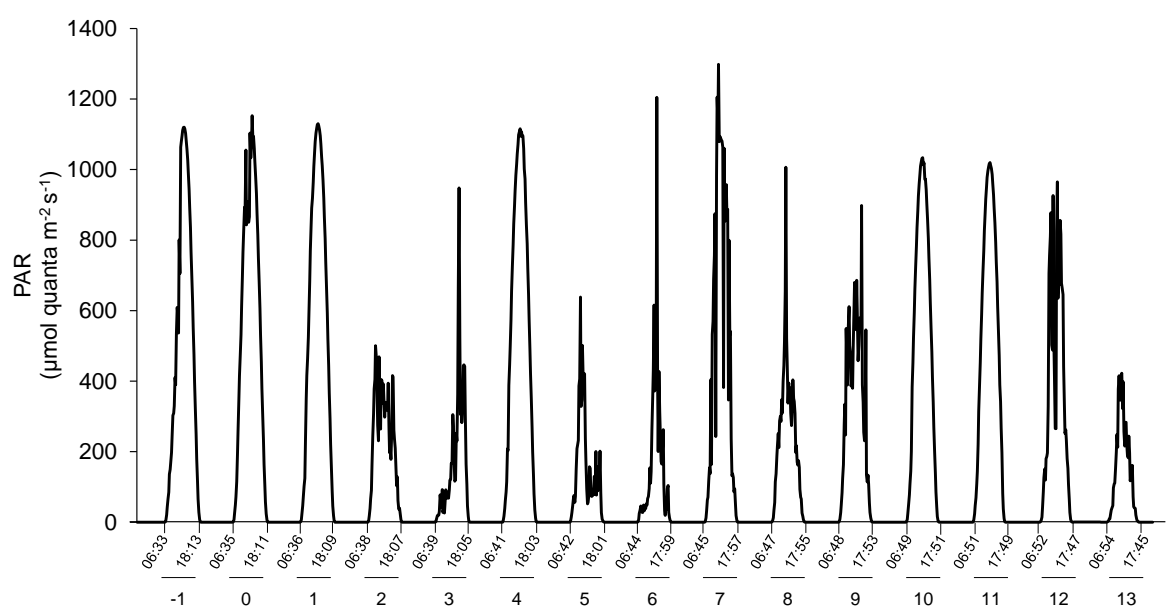

Figure 2. Changes in incident photosynthetic active radiation (PAR) at the top of the mesocosm level during the experiment as measured by a Satlantic HyperOCR hyperspectral radiometer and integrated into the 400-700 nm range. Local sunrise and sunset times (EDT) are indicated with the corresponding days of the experiment.

automatic system controlled the sporadic addition of $\mathrm{CO}_{2}$ saturated water to stop the $\mathrm{pH}$ from rising. Only the Drifters were not controlled throughout the experiment. Incident light was variable during our experiment, with only a few sunny days (Fig. 2).

\subsection{Seawater analysis}

The mesocosms were sampled between 05:00 and 08:00 Eastern Daylight Time (EDT) every day. Seawater for carbonate chemistry, nutrients, and primary production was collected directly from the mesocosms as close to sunrise as possible. Seawater was also collected in $20 \mathrm{~L}$ carboys for the determination of chlorophyll $a(\mathrm{Chl} a)$, taxonomy, and other variables. The total amount of volume sampled every day was $24 \mathrm{~L}$ or less. Samples for salinity were taken from the artificial seawater tanks and in the mesocosms on days $-3,3$, and 13 . The samples were collected in $250 \mathrm{~mL}$ plastic bottles and stored in the dark until analysis was performed using a Guildline Autosal 8400B Salinometer during the following months.

\subsubsection{Carbonate chemistry}

Carbonate chemistry parameters were determined using methods described in Mucci et al. (2018). Briefly, water samples for $\mathrm{pH}$ (every day) and total alkalinity (TA, every 34 days) measurements were, respectively, transferred from the mesocosms to $125 \mathrm{~mL}$ plastic bottles without headspace and $250 \mathrm{~mL}$ glass bottles. A few crystals of $\mathrm{HgCl}_{2}$ were added to the glass bottles before sealing them with a groundglass stopper and Apiezon ${ }^{\circledR}$ Type-M high-vacuum grease. The $\mathrm{pH}$ was determined within hours of collection, after thermal equilibration at $25.0 \pm 0.1{ }^{\circ} \mathrm{C}$, using a Hewlett-Packard UV-Visible diode array spectrophotometer (HP-8453A) and a $5 \mathrm{~cm}$ quartz cell with phenol red (PR; Robert-Baldo et al., 1985) and $m$-cresol purple (mCP; Clayton and Byrne, 1993) as indicators. Measurements were carried out at the wavelength of maximum absorbance of the protonated (HL) and deprotonated (L) indicators. Comparable measurements were carried out using a TRIS buffer prepared at a practical salinity of 25 before and after each set of daily measurements (Millero, 1986).

The $\mathrm{pH}$ on the total proton concentration scale $\left(\mathrm{pH}_{\mathrm{T}}\right)$ of the buffer solutions and samples at $25^{\circ} \mathrm{C}$ was calculated according to the equation of Byrne (1987), using the salinity of each sample and the $\mathrm{HSO}_{4}^{-}$association constants given by Dickson (1990). The TA was determined on site within 1 day of sampling by open-cell automated potentiometric titration (Titrilab 865, Radiometer ${ }^{\circledR}$ ) with a pH combination electrode $\left(\mathrm{pHC} 2001, \operatorname{Red} \operatorname{Rod}^{\circledR}\right)$ and a dilute $(0.025 \mathrm{~N}) \mathrm{HCl}$ titrant solution. The titrant was calibrated using Certified Reference Materials (CRM Batch\#94, provided by Andrew Dickson, Scripps Institute of Oceanography, La Jolla, USA). The average relative error, based on the average relative standard deviation on replicate standard and sample analyses, was better than $0.15 \%$. The carbonate chemistry parameters at in situ temperature were then calculated using the computed $\mathrm{pH}_{\mathrm{T}}$ at $25^{\circ} \mathrm{C}$ in combination with the measured TA using $\mathrm{CO}_{2} \mathrm{SYS}$ (Pierrot et al., 2006) and the carbonic acid dissociation constants of Cai and Wang (1998).

\subsubsection{Nutrients}

Samples for $\mathrm{NO}_{3}^{-}, \mathrm{Si}(\mathrm{OH})_{4}$, and SRP analyses were collected directly from the mesocosms every day, filtered through Whatman $\mathrm{GF} / \mathrm{F}$ filters and stored at $-20^{\circ} \mathrm{C}$ in acid washed polyethylene tubes until analysis by a Bran and Luebbe Autoanalyzer III using the colorimetric methods described by Hansen and Koroleff (2007). The analyti- 
cal detection limit was $0.03 \mu \mathrm{mol} \mathrm{L}-1$ for $\mathrm{NO}_{3}^{-}$plus nitrite $\left(\mathrm{NO}_{2}^{-}\right), 0.02 \mu \mathrm{mol} \mathrm{L}^{-1}$ for $\mathrm{NO}_{2}^{-}, 0.1 \mu \mathrm{mol} \mathrm{L}^{-1}$ for $\mathrm{Si}(\mathrm{OH})_{4}$, and $0.05 \mu \mathrm{mol} \mathrm{L}^{-1}$ for SRP.

\subsubsection{Plankton biomass, composition, and enumeration}

Duplicate subsamples $(100 \mathrm{~mL})$ for $\mathrm{Chl} a$ determination were filtered onto Whatman GF/F filters. Chl $a$ concentrations were measured using a 10-AU Turner Designs fluorometer, following a $24 \mathrm{~h}$ extraction in $90 \%$ acetone at $4{ }^{\circ} \mathrm{C}$ in the dark without grinding (acidification method: Parsons et al., 1984). The analytical detection limit for Chl $a$ was $0.05 \mu \mathrm{g} \mathrm{L}{ }^{-1}$.

Pico- $(0.2-2 \mu \mathrm{m})$ and nano-phytoplankton $(2-20 \mu \mathrm{m})$ cell abundances were determined daily by flow cytometry. Sterile cryogenic polypropylene vials were filled with $4.95 \mathrm{~mL}$ of seawater to which $50 \mu \mathrm{L}$ of glutaraldehyde Grade I (final concentration $=0.1 \%$, Sigma Aldrich; Marie et al., 2005) were added. Duplicate samples were flash frozen in liquid nitrogen after standing $15 \mathrm{~min}$ at room temperature in the dark. These samples were then stored at $-80^{\circ} \mathrm{C}$ until analysis. After thawing to ambient temperature, samples were analyzed using a FACS Calibur flow cytometer (Becton Dickinson) equipped with a $488 \mathrm{~nm}$ argon laser. The abundances of nanophytoplankton and picophytoplankton, which include photosynthetic picoeukaryotes and picocyanobacteria, were determined by their autofluorescence characteristics and size (Marie et al., 2005). The biomass accumulation and nanophytoplankton growth rates were calculated by the following equation:

$\mu=\ln \left(N_{2} / N_{1}\right) /\left(t_{2}-t_{1}\right)$,

where $N_{1}$ and $N_{2}$ are the biomass or cell concentrations at given times $t_{1}$ and $t_{2}$, respectively.

Microscopic identification and enumeration for eukaryotic cells larger than $2 \mu \mathrm{m}$ were conducted on samples taken from each mesocosm on three days: day -4 , the day when maximum Chl $a$ was attained in each mesocosm, and day 13. Samples of $250 \mathrm{~mL}$ were collected and preserved with acidic Lugol solution (Parsons et al., 1984), and then stored in the dark until analysis. Cell identification was carried out at the lowest possible taxonomic rank using an inverted microscope (Zeiss Axiovert 10) in accordance with Lund et al. (1958). The main taxonomic references used to identify the phytoplankton were Tomas (1997) and Bérard-Therriault et al. (1999).

\subsubsection{Primary production}

Primary production was determined daily using the ${ }^{14} \mathrm{C}$ fixation incubation method (Knap et al., 1996; Ferland et al., 2011). One clear and one dark $250 \mathrm{~mL}$ polycarbonate bottle were filled from each mesocosm at dawn and spiked with $250 \mu \mathrm{L}$ of $\mathrm{NaH}^{14} \mathrm{CO}_{3}\left(80 \mu \mathrm{CimL}{ }^{-1}\right)$. One hundred $\mu \mathrm{L}$ of 3-(3,4-dichlorophenyl)-1,1-dimethylurea (DCMU; $0.02 \mathrm{~mol} \mathrm{~L}^{-1}$ ) was added to the dark bottles to pre- vent active fixation of ${ }^{14} \mathrm{C}$ by phytoplankton (Legendre et al., 1983). The total amount of radioisotope in each bottle was determined by immediately pipetting $50 \mu \mathrm{L}$ subsamples into a $20 \mathrm{~mL}$ scintillation vial containing $10 \mathrm{~mL}$ of scintillation cocktail (Ecolume ${ }^{\mathrm{TM}}$ ) and $50 \mu \mathrm{L}$ of ethanolamine (Sigma). Bottles were placed in separate incubators, at either $10^{\circ} \mathrm{C}$ or $15^{\circ} \mathrm{C}$, under reduced $(30 \%)$ natural light for $24 \mathrm{~h}$, which corresponds to the light transmittance at mid-mesocosm depth.

At the end of the incubation periods, $3 \mathrm{~mL}$ was transferred to a scintillation vial for determination of the total primary production $\left(P_{\mathrm{T}}\right)$, and $3 \mathrm{~mL}$ was filtered through a syringe filter $(\mathrm{GD} / \mathrm{X} 0.7 \mu \mathrm{m})$ to estimate daily photosynthetic carbon fixation released in the dissolved organic carbon pool $\left(P_{\mathrm{D}}\right)$. The remaining volume was filtered onto a Whatman GF/F filter to measure the particulate primary production $\left(P_{\mathrm{P}}\right)$. Vials containing the $P_{\mathrm{T}}$ and $P_{\mathrm{D}}$ samples were acidified with $500 \mu \mathrm{L}$ of $\mathrm{HCl} 6 \mathrm{~N}$, allowed to sit for $3 \mathrm{~h}$ under a fume hood, and then neutralized with $500 \mu \mathrm{L}$ of $\mathrm{NaOH} 6 \mathrm{~N}$. The vials containing the filters were acidified with $100 \mu \mathrm{L}$ of $0.05 \mathrm{~N} \mathrm{HCl}$ and left to fume for $12 \mathrm{~h}$. Fifteen $\mathrm{mL}$ of a scintillation cocktail was added to the vials and was stored pending analysis using a Tri-Carb 4910TR liquid scintillation counter (PerkinElmer). Rates of carbon fixation into particulate and dissolved organic matter were calculated according to Knap et al. (1996) using the dissolved inorganic carbon concentration computed for each mesocosm at the beginning of the daily incubations and multiplied by a factor of 1.05 to correct for the lower uptake of ${ }^{14} \mathrm{C}$ compared to ${ }^{12} \mathrm{C}$.

\subsection{Statistical analysis}

All statistical analyses were performed using R (nlme package). A general least squares (gls) model approach was used to test the linear effects of the two treatments (temperature, $\left.p \mathrm{CO}_{2}\right)$, and of their interactions on the measured variables (Paul et al., 2016; Hussherr et al., 2017). The analysis was conducted independently on two different time periods: Phase I (day 0 to day of maximum Chl $a$ concentration) was calculated individually for each mesocosm, whereas Phase II (day after maximum $\mathrm{Chl} a$ concentrations) corresponded to the declining phase of the bloom (Table 1). Averages (or time integration in the case of primary production) of the response variables were calculated separately over the two phases and were plotted against $p \mathrm{CO}_{2}$. Separate regressions were performed with $p \mathrm{CO}_{2}$ as the continuous factor for each temperature when a temperature effect or interaction with $p \mathrm{CO}_{2}$ was detected in the gls model. Otherwise, the model included data from both temperatures and the interaction with $p \mathrm{CO}_{2}$. Normality of the residuals was determined using a ShapiroWilk test $(p>0.05)$ and data were transformed (natural logarithm or square root) if required. As explained by Havenhand et al. (2010), the gradient approach, instead of treatment replication, is particularly suitable when few experimental units are available such as in large-volume mesocosm experiments. In addition, squared Pearson's correlation coefficients 
Table 1. Day of maximum $\mathrm{Chl} a$ concentration, the associated average $\mathrm{pH}_{\mathrm{T}}$ (total hydrogen ion scale), and average $p \mathrm{CO}_{2}$ over each individually defined phase. Phase I is defined from day 0 until the day of maximum Chl $a$ for each mesocosm, while Phase II is defined from the day after maximum Chl $a$ until day 13. Average temperature over day 0 to day 13 is also presented for each mesocosm. Average values are presented with \pm standard errors.

\begin{tabular}{|c|c|c|c|c|c|c|}
\hline \multirow[b]{2}{*}{ Mesocosm } & \multirow[b]{2}{*}{$\begin{array}{c}\text { Day of } \\
\max \text { Chl } a\end{array}$} & \multicolumn{2}{|c|}{ Phase I } & \multicolumn{2}{|c|}{ Phase II } & \multirow{2}{*}{$\begin{array}{c}\text { Day } 0-13 \\
\text { Temperature } \\
\left({ }^{\circ} \mathrm{C}\right)\end{array}$} \\
\hline & & $\mathrm{pH}_{\mathrm{T}}$ & $\begin{array}{l}p \mathrm{CO}_{2} \\
(\mu \mathrm{atm})\end{array}$ & $\mathrm{pH}_{\mathrm{T}}$ & $\begin{array}{l}p \mathrm{CO}_{2} \\
(\mu \mathrm{atm})\end{array}$ & \\
\hline $\mathrm{M} 1\left(7.4-10^{\circ} \mathrm{C}\right)$ & 4 & $7.32 \pm 0.01$ & $2231 \pm 25$ & $7.28 \pm 0.02$ & $2437 \pm 92$ & $10.06 \pm 0.01$ \\
\hline $\mathrm{M} 2\left(8.0-10^{\circ} \mathrm{C}\right)$ & 4 & $7.84 \pm 0.01$ & $628 \pm 16$ & $7.74 \pm 0.03$ & $814 \pm 65$ & $10.00 \pm 0.01$ \\
\hline $\mathrm{M} 3\left(7.6-10^{\circ} \mathrm{C}\right)$ & 7 & $7.54 \pm 0.01$ & $1294 \pm 18$ & $7.48 \pm 0.02$ & $1503 \pm 64$ & $10.07 \pm 0.01$ \\
\hline $\mathrm{M} 4\left(7.8-10^{\circ} \mathrm{C}\right)$ & 4 & $7.71 \pm 0.01$ & $868 \pm 13$ & $7.66 \pm 0.01$ & $976 \pm 29$ & $10.04 \pm 0.01$ \\
\hline $\operatorname{M5}\left(7.2-10^{\circ} \mathrm{C}\right)$ & 7 & $7.17 \pm 0.01$ & $3122 \pm 35$ & $7.15 \pm 0.01$ & $3315 \pm 94$ & $10.03 \pm 0.01$ \\
\hline M6 (Drifter $-10^{\circ} \mathrm{C}$ ) & 4 & $7.93 \pm 0.01$ & $503 \pm 15$ & $8.22 \pm 0.03$ & $251 \pm 25$ & $10.02 \pm 0.01$ \\
\hline $\mathrm{M} 7\left(7.4-15^{\circ} \mathrm{C}\right)$ & 4 & $7.38 \pm 0.01$ & $2004 \pm 44$ & $7.31 \pm 0.02$ & $2399 \pm 120$ & $15.00 \pm 0.01$ \\
\hline $\mathrm{M} 8\left(7.2-15^{\circ} \mathrm{C}\right)$ & 2 & $7.21 \pm 0.01$ & $2961 \pm 58$ & $7.18 \pm 0.01$ & $3179 \pm 74$ & $15.01 \pm 0.01$ \\
\hline $\mathrm{M} 9\left(8.0-15^{\circ} \mathrm{C}\right)$ & 2 & $7.85 \pm 0.01$ & $454 \pm 13$ & $7.79 \pm 0.02$ & $545 \pm 25$ & $15.03 \pm 0.01$ \\
\hline $\operatorname{M} 10\left(7.6-15^{\circ} \mathrm{C}\right)$ & 2 & $7.54 \pm 0.01$ & $1364 \pm 22$ & $7.44 \pm 0.02$ & $1746 \pm 106$ & $14.94 \pm 0.01$ \\
\hline M11 (Drifter- $\left.15^{\circ} \mathrm{C}\right)$ & 1 & $8.07 \pm 0.01$ & $388 \pm 90$ & $8.59 \pm 0.02$ & $84 \pm 7$ & $14.96 \pm 0.02$ \\
\hline $\mathrm{M} 12\left(7.8-15^{\circ} \mathrm{C}\right)$ & 2 & $7.67 \pm 0.01$ & $1001 \pm 31$ & $7.59 \pm 0.01$ & $1215 \pm 44$ & $14.98 \pm 0.02$ \\
\hline
\end{tabular}

$\left(r^{2}\right)$ with a significance level of 0.05 were used to evaluate correlations between key variables.

\section{Results}

\subsection{Seawater chemistry}

Water salinity was $26.52 \pm 0.03$ on day -4 in all mesocosms and remained constant throughout the experiment, averaging $26.54 \pm 0.02$ on day 13 . The TA was practically invariant in the mesocosms, averaging $2057 \pm 2 \mu \mathrm{mol} \mathrm{kg}_{\mathrm{sw}}^{-1}$ on day -4 and $2058 \pm 2 \mu \mathrm{mol} \mathrm{kg}-1$ on day 13. Following the filling of the mesocosms, the $\mathrm{pH}_{\mathrm{T}}$ in all mesocosms decreased from an average of 7.84 to 7.53 . Throughout the rest of the experiment after treatments were applied, the $\mathrm{pH}$ remained relatively stable in the $\mathrm{pH}$-controlled treatments, but decreased slightly during Phase II by an average of $-0.14 \pm 0.07$ units relative to the target $\mathrm{pH}_{\mathrm{T}}$ (Fig. 3a). Given a constant TA, $\mathrm{pH}$ variations were accompanied by variations in $p \mathrm{CO}_{2}$, from an average of $1340 \pm 150 \mu \mathrm{atm}$ on day -3 , and ranging from 564 to $2902 \mu \mathrm{atm}$ at $10^{\circ} \mathrm{C}$, and from 363 to $2884 \mu \mathrm{atm}$ at $15^{\circ} \mathrm{C}$ on day 0 following the acidification (Fig. 3b; Table 1). The $\mathrm{pH}_{\mathrm{T}}$ in the Drifters (M6 and M11) increased from 7.896 and 7.862 on day 0 at 10 and $15^{\circ} \mathrm{C}$, respectively, to 8.307 and 8.554 on day 13 , reflecting the balance between $\mathrm{CO}_{2}$ uptake and metabolic $\mathrm{CO}_{2}$ production over the duration of the experiment. On the last day, $p \mathrm{CO}_{2}$ in all mesocosms ranged from 186 to $3695 \mu \mathrm{atm}$ at $10^{\circ} \mathrm{C}$, and from 90 to $3480 \mu \mathrm{atm}$ at $15^{\circ} \mathrm{C}$. The temperature of the mesocosms in each container remained within $\pm 0.1^{\circ} \mathrm{C}$ of the target temperature throughout the experiment and averaged $10.04 \pm 0.02{ }^{\circ} \mathrm{C}$ for meso- cosms M1 through M6, and $15.0 \pm 0.1{ }^{\circ} \mathrm{C}$ for mesocosms M7 through M12 (Fig. 3c; Table 1).

\subsection{Dissolved inorganic nutrient concentrations}

Nutrient concentrations averaged $9.1 \pm 0.5 \mu \mathrm{mol} \mathrm{L}^{-1}$ for $\mathrm{NO}_{3}^{-}, \quad 13.4 \pm 0.3 \mu \mathrm{mol} \mathrm{L}^{-1}$ for $\mathrm{Si}(\mathrm{OH})_{4}, \quad$ and $0.91 \pm 0.03 \mu \mathrm{mol} \mathrm{L}^{-1}$ for SRP on day 0 (Fig. 3d, e, f). Within individual mesocosms, concentrations of nitrate, silicic acid, and soluble reactive phosphate displayed similar temporal patterns following the development of the phytoplankton bloom. Overall, $\mathrm{NO}_{3}^{-}$depletion was reached within 5 days in all mesocosms at $10^{\circ} \mathrm{C}$, except for the Drifter, which became nutrient-depleted by day 3 . Nutrient depletion was reached slightly earlier within the $15^{\circ} \mathrm{C}$ mesocosms, all of them displaying exhaustion within 3 days of the experiment. Accordingly, bloom development and primary production within each mesocosm were eventually limited by the supply in nutrients, irrespective of the temperature or $\mathrm{pH}$ treatment. Likewise, $\mathrm{Si}(\mathrm{OH})_{4}$ fell below the detection limit between days 1 and 5 in all mesocosms except for those whose $\mathrm{pH}_{\mathrm{T}}$ was set at 7.2 and 7.6 at $10^{\circ} \mathrm{C}(\mathrm{M} 5$ and M3) and in which $\mathrm{Si}(\mathrm{OH})_{4}$ depletion occurred on day 9. Variations in SRP concentrations followed closely those of $\mathrm{NO}_{3}^{-}$in all mesocosms, except again for those set at $\mathrm{pH} 7.2$ and 7.6, in which undetectable values were reached on day 9 .

\subsection{Phytoplankton biomass}

Chl $a$ concentrations were below $1 \mu \mathrm{g} \mathrm{L}{ }^{-1}$ just after the filling of the mesocosms, and averaged $5.9 \pm 0.6 \mu \mathrm{g} \mathrm{L}^{-1}$ on day 0 (Fig. 4a). They then quickly increased to reach maximum concentrations around $27 \pm 2 \mu \mathrm{gL}^{-1}$ on day $3 \pm 2$, and decreased progressively until the end of the experiment, reach- 
Table 2. Results of the generalized least squares models (gls) tests for the effects of temperature. $p \mathrm{CO}_{2}$ and their interaction during Phase I (day 0 to the day of maximum $\mathrm{Chl} a$ concentration). Separate analyses with $p \mathrm{CO}_{2}$ as a continuous factor were performed when temperature had a significant effect. Chl $a$ concentration, nanophytoplankton abundance, picoeukaryote abundance, picocyanobacteria abundance, particulate and dissolved primary production, and $\mathrm{Chl} a$-normalized particulate and dissolved primary production. Significant results are in bold.

\begin{tabular}{|c|c|c|c|c|}
\hline Response variable & Factor & df & $t$-value & $p$-value \\
\hline \multirow{3}{*}{$\begin{array}{l}\text { Mean Chl } a \text { concentration } \\
\left(\mu \mathrm{g} \mathrm{L}^{-1}\right)\end{array}$} & Temperature & 8 & 2.004 & 0.080 \\
\hline & $p \mathrm{CO}_{2}$ & 8 & -0.464 & 0.655 \\
\hline & $p \mathrm{CO}_{2} \times$ temperature & 8 & 0.244 & 0.813 \\
\hline \multirow{3}{*}{$\begin{array}{l}\text { Mean nanophytoplankton abundance } \\
\left(\times 10^{6} \text { cells } \mathrm{L}^{-1}\right)\end{array}$} & Temperature & 8 & 2.725 & 0.026 \\
\hline & $p \mathrm{CO}_{2}\left(10^{\circ} \mathrm{C}\right)$ & 4 & -2.285 & 0.084 \\
\hline & $p \mathrm{CO}_{2}\left(15^{\circ} \mathrm{C}\right)$ & 4 & -1.191 & 0.299 \\
\hline \multirow{3}{*}{$\begin{array}{l}\text { Mean picoeukaryote abundance } \\
\left(\times 10^{6} \text { cells } L^{-1}\right)\end{array}$} & Temperature & 8 & 1.056 & 0.322 \\
\hline & $p \mathrm{CO}_{2}$ & 8 & -1.159 & 0.280 \\
\hline & $p \mathrm{CO}_{2} \times$ temperature & 8 & 1.125 & 0.293 \\
\hline \multirow{3}{*}{$\begin{array}{l}\text { Mean picocyanobacteria abundance } \\
\left(\times 10^{6} \text { cells } L^{-1}\right)\end{array}$} & Temperature & 8 & 0.891 & 0.399 \\
\hline & $p \mathrm{CO}_{2}$ & 8 & 0.991 & 0.351 \\
\hline & $p \mathrm{CO}_{2} \times$ temperature & 8 & -1.166 & 0.277 \\
\hline \multirow{3}{*}{ 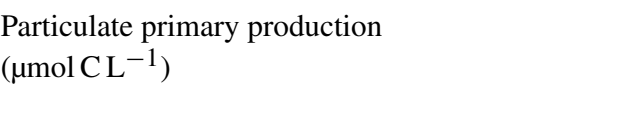 } & Temperature & 8 & -0.124 & 0.905 \\
\hline & $p \mathrm{CO}_{2}$ & 8 & -1.011 & 0.342 \\
\hline & $p \mathrm{CO}_{2} \times$ temperature & 8 & 0.867 & 0.411 \\
\hline \multirow{3}{*}{$\begin{array}{l}\text { Dissolved primary production } \\
\left(\mu \mathrm{mol} \mathrm{CL} \mathrm{L}^{-1}\right)\end{array}$} & Temperature & 8 & -1.429 & 0.191 \\
\hline & $p \mathrm{CO}_{2}$ & 8 & -0.569 & 0.585 \\
\hline & $p \mathrm{CO}_{2} \times$ temperature & 8 & 0.723 & 0.490 \\
\hline \multirow{3}{*}{$\begin{array}{l}\text { Chl } a \text {-normalized particulate primary production } \\
\left(\mu \mathrm{mol} \mathrm{C}(\mu \mathrm{g} \mathrm{Chl} a)^{-1} \mathrm{~d}^{-1}\right)\end{array}$} & Temperature & 8 & 1.689 & 0.130 \\
\hline & $p \mathrm{CO}_{2}$ & 8 & 0.107 & 0.918 \\
\hline & $p \mathrm{CO}_{2} \times$ temperature & 8 & -0.381 & 0.713 \\
\hline \multirow{3}{*}{$\begin{array}{l}\text { Chl } a \text {-normalized dissolved primary production } \\
\left(\mu \mathrm{mol} \mathrm{C}(\mu \mathrm{g} \mathrm{Chl} a)^{-1} \mathrm{~d}^{-1}\right)\end{array}$} & Temperature & 8 & -1.046 & 0.326 \\
\hline & $p \mathrm{CO}_{2}$ & 8 & -0.381 & 0.713 \\
\hline & $p \mathrm{CO}_{2} \times$ temperature & 8 & 0.449 & 0.665 \\
\hline
\end{tabular}

ing $11 \pm 1$ and $2.4 \pm 0.2 \mu \mathrm{g} \mathrm{L}-1$ at 10 and $15^{\circ} \mathrm{C}$ on day 13 . During Phase I, results from the gls model show no significant relationships between the mean Chl $a$ concentrations and $p \mathrm{CO}_{2}$, temperature, and the interaction of the two factors (Fig. 4b; Table 2). During this phase, the accumulation rate of Chl $a$ was positively affected by temperature, increasing by $\sim 76 \%$, but was not affected by the $p \mathrm{CO}_{2}$ gradient at either temperature (Fig. 5a; Table 3). The maximum Chl $a$ concentrations reached during the bloom were not affected by the two treatments (Fig. 5b; Table 3). During Phase II, we observed no significant effect of $p \mathrm{CO}_{2}$, temperature, and the interaction of those factors on the mean $\mathrm{Chl} a$ concentrations following the depletion of $\mathrm{NO}_{3}^{-}$(Fig. 4c; Table 4).

\subsection{Phytoplankton size class}

Nanophytoplankton abundance varied from $8 \pm 1 \times$ $10^{6}$ cells $\mathrm{L}^{-1}$ on day 0 to an average maximum of $36 \pm 10 \times 10^{6}$ cells $\mathrm{L}^{-1}$ at the peak of the bloom (Fig. 4d). At both temperatures, nanophytoplankton abundance increased until at least days 2 or 4 and decreased or remained stable thereafter. The correlation between the nanophytoplankton abundance and Chl $a\left(r^{2}=0.75, p<0.001, \mathrm{df}=166\right)$ suggests that this phytoplankton size class was responsible for most of the biomass build-up throughout the experiment. As observed for the mean Chl $a$ concentration, the mean abundance of nanophytoplankton was not significantly affected by the $p \mathrm{CO}_{2}$ gradient at the two temperatures investigated during Phase I, but showed higher values at $15^{\circ} \mathrm{C}$ $\left(26 \pm 2 \times 10^{6}\right.$ cells $\left.\mathrm{L}^{-1}\right)$ than at $10^{\circ} \mathrm{C}\left(14 \pm 1 \times 10^{6}\right.$ cells $\left.\mathrm{L}^{-1}\right)$ (Fig. 4e; Table 2). Likewise, the growth rate of nanophytoplankton during Phase I was not influenced by the $p \mathrm{CO}_{2}$ gradient at the two temperatures, but was significantly higher in the warm treatment (Fig. 5c; Table 3). During Phase II, no relationship was found between the mean nanophytoplankton abundance and the $p \mathrm{CO}_{2}$ gradient, the temperature, and the $p \mathrm{CO}_{2} \times$ temperature interaction (Fig. 4f; Table 4).

Initial abundance of photosynthetic picoeukaryotes was $10 \pm 2 \times 10^{6}$ cells $\mathrm{L}^{-1}$, accounting for more than $80 \%$ of 

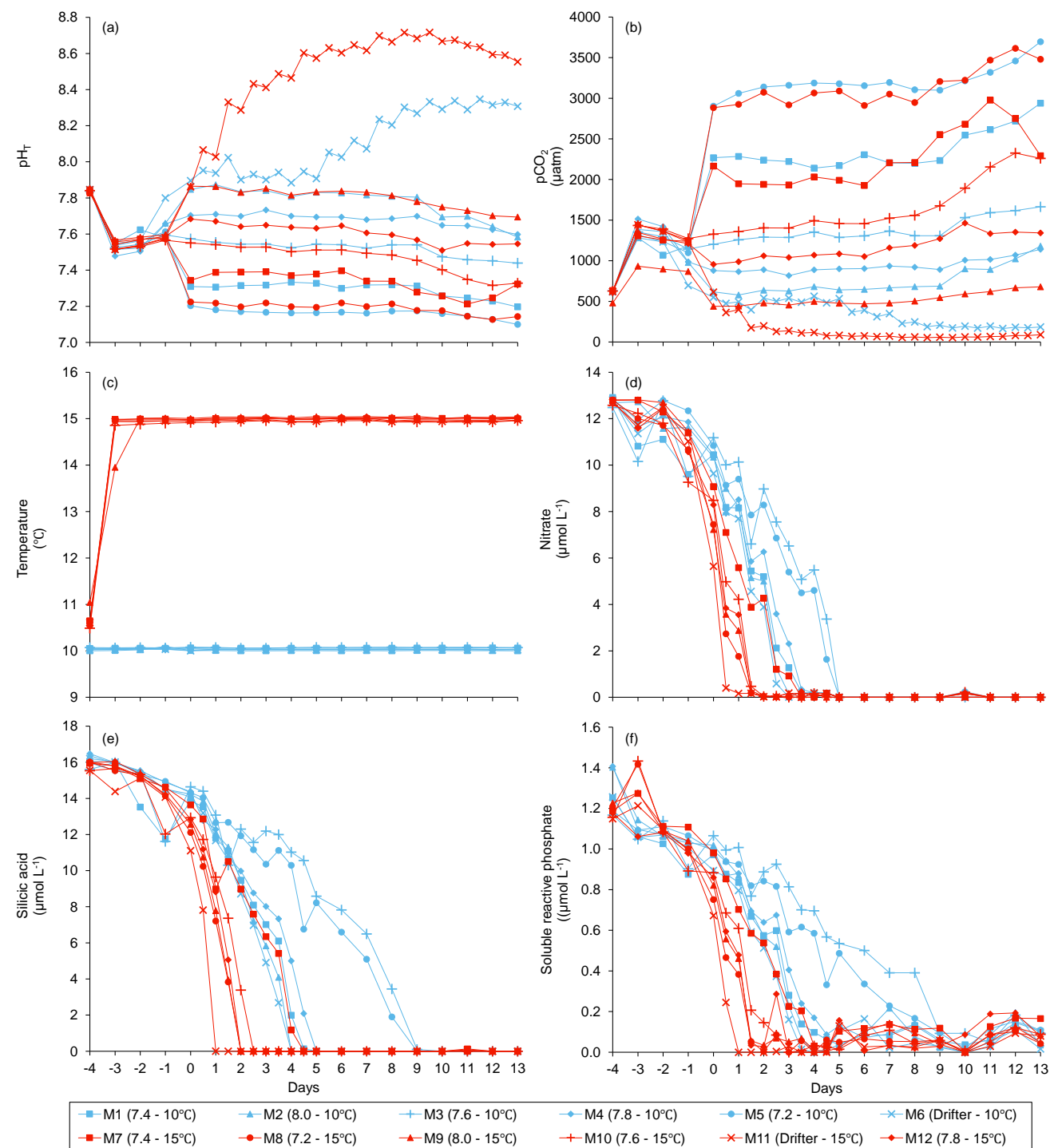

Figure 3. Temporal variations over the course of the experiment for (a) $\mathrm{pH}_{\mathrm{T}}$, (b) $p \mathrm{CO}_{2}$, (c) temperature, (d) nitrate, (e) silicic acid, and (f) soluble reactive phosphate. For symbol attribution to treatments, see legend.

total plankton cells in the $0.2-20 \mu \mathrm{m}$ size fraction. The abundance of this plankton size fraction decreased slightly through Phase I and their number remained relatively stable at $4 \pm 3 \times 10^{6}$ cells $\mathrm{L}^{-1}$ throughout Phase II (Fig. $4 \mathrm{~g}$ ). We found no relationship between the abundance of picoeukaryotes and the $p \mathrm{CO}_{2}$ gradient at the two temperatures investigated during both Phases I and II, and no temperature effect was observed either (Fig. 4h, i; Tables 2 and 4).

Picocyanobacteria exhibited a different pattern than the nanophytoplankton and picoeukaryotes (Fig. 4j). Their abundance was initially low $\left(1.7 \pm 0.3 \times 10^{6}\right.$ cells $\mathrm{L}^{-1}$ on day 0$)$, remained relatively stable during Phase $\mathrm{I}$, and increased rapidly during Phase II, accounting for $\sim 50 \%$ of the total picophytoplankton cell counts toward the end of the exper- iment. During Phase I, the mean picocyanobacteria abundance was not influenced by the $p \mathrm{CO}_{2}$ gradient or temperature (Fig. 4k; Table 2). During Phase II, the mean picocyanobacteria abundance was not significantly affected by $p \mathrm{CO}_{2}$ at in situ temperature. However, mean picocyanobacteria were higher at $15^{\circ} \mathrm{C}$, with the $p \mathrm{CO}_{2}$ gradient responsible for a $\sim 33 \%$ reduction of picocyanobacteria abundance from the Drifter to the more acidified treatment $(4.4 \pm 0.2 \times$ $10^{6}$ cells L $^{-1}$ vs. $3.0 \pm 0.3 \times 10^{6}$ cells L $^{-1}$ ) (Fig. 4l; Table 4).

\subsection{Phytoplankton taxonomy}

The taxonomic composition of the planktonic assemblage larger than $2 \mu \mathrm{m}$ was identical in all treatments at the begin- 

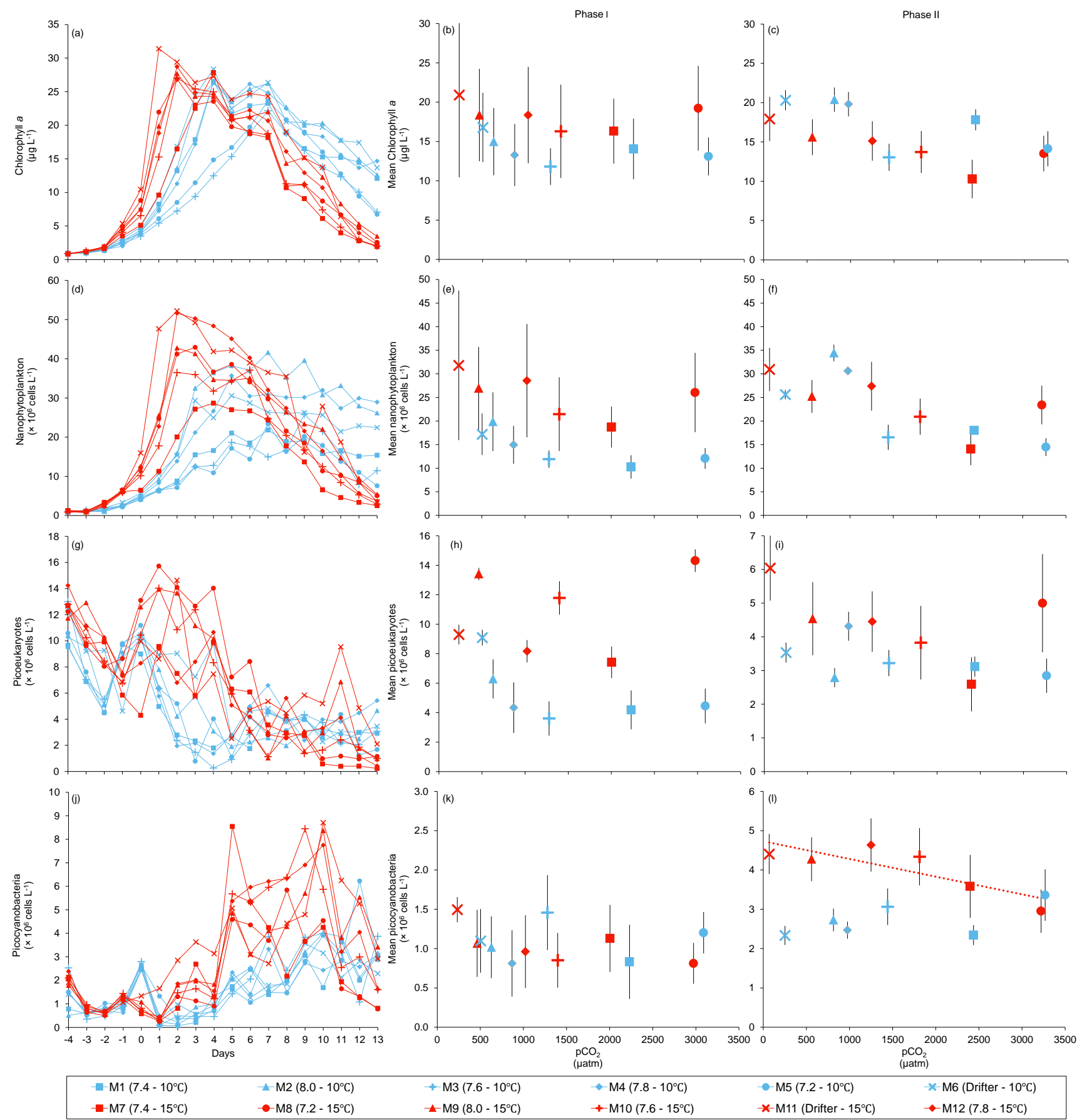

Figure 4. Temporal variations and averages \pm SE during Phase I (day 0 to day of maximum Chl $a$ concentration) and Phase II (day after maximum Chl $a$ concentration to day 13) for (a-c) chlorophyll $a,(\mathbf{d}-\mathbf{f})$ nanophytoplankton, $(\mathbf{g}-\mathbf{i})$ picoeukaryotes, and (j-l) picocyanobacteria. For symbol attribution to treatments, see legend.

ning of the experiment, and was mainly composed of the cosmopolitan chain-forming centric diatom Skeletonema costatum (S. costatum) and the cryptophyte Plagioselmis prolonga var. nordica (Fig. 6). At the peak of the blooms (maximum Chl $a$ concentrations), the species composition did not vary between the $p \mathrm{CO}_{2}$ treatments and between the two tem- peratures tested. $S$. costatum was the dominant species in all mesocosms (70-90\% of the total number of eukaryotic cells), except for one mesocosm (M3, pH 7.6 at $10^{\circ} \mathrm{C}$ ) where a mixed dominance of Chrysochromulina spp. (a prymnesiophyte of 2-5 $\mu \mathrm{m}$ ) and $S$. costatum was observed (Fig. 6a). S. costatum accounted for $80-90 \%$ of the total eukaryotic 


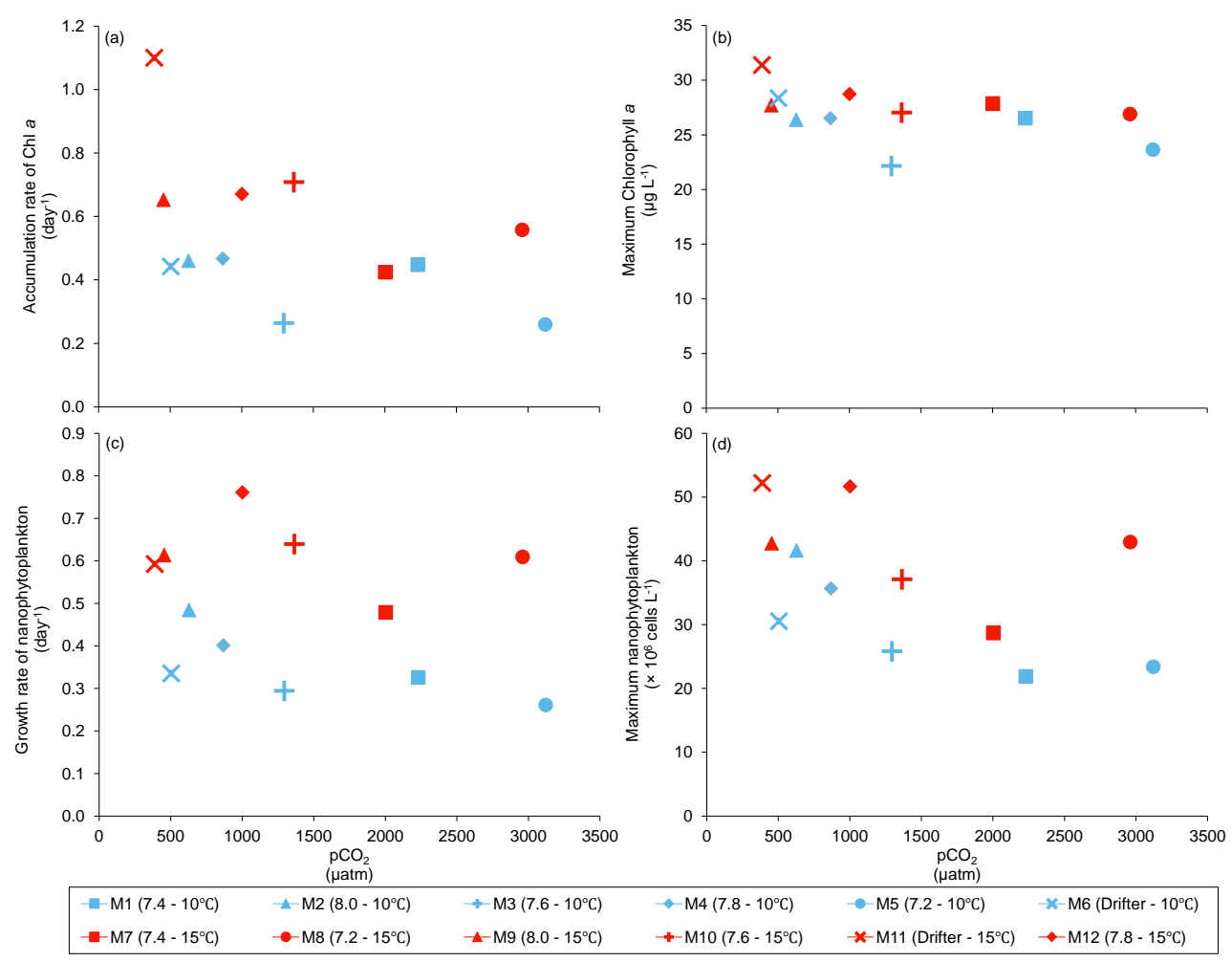

Figure 5. (a) Accumulation rate of Chl $a$ (day 0 to maximum Chl $a$ concentration), (b) maximum Chl $a$ concentrations, (c) growth rate of nanophytoplankton (day 0 to maximum nanophytoplankton abundance), and (d) maximum nanophytoplankton abundance during the experiment. For symbol attribution to treatments, see legends.

Table 3. Results of the generalized least squares models (gls) tests for the effects of temperature, $p \mathrm{CO}_{2}$, and their interaction. Separate analyses with $p \mathrm{CO}_{2}$ as a continuous factor were performed when temperature had a significant effect. Accumulation rate of Chl $a$ (day 0 to maximum $\mathrm{Chl} a$ concentration), maximum $\mathrm{Chl} a$ concentration, growth rate of nanophytoplankton (day 0 to maximum nanophytoplankton abundance), and maximum nanophytoplankton abundance. Significant results are in bold.

\begin{tabular}{llrrr}
\hline Response variable & Factor & df & $t$-value & $p$-value \\
\hline Accumulation rate of $\mathrm{Chl} a$ & Temperature & $\mathbf{8}$ & $\mathbf{2 . 6 7 9}$ & $\mathbf{0 . 0 2 8}$ \\
$\left(\right.$ day $\left.^{-1}\right)$ & $p \mathrm{CO}_{2}\left(10^{\circ} \mathrm{C}\right)$ & 4 & -1.476 & 0.214 \\
& $p \mathrm{CO}_{2}\left(15^{\circ} \mathrm{C}\right)$ & 4 & -1.759 & 0.154 \\
\hline Maximum $\mathrm{Chl} a$ concentration & Temperature & 8 & 1.305 & 0.228 \\
$\left(\mu \mathrm{g} \mathrm{L}^{-1}\right)$ & $p \mathrm{CO}_{2}$ & 8 & -0.387 & 0.709 \\
& $p \mathrm{CO}_{2} \times$ temperature & 8 & 0.022 & 0.983 \\
\hline Growth rate of nanophytoplankton & $\left.\mathrm{Temperature}^{-1}\right)$ & $\mathbf{8}$ & $\mathbf{2 . 5 3 4}$ & $\mathbf{0 . 0 3 5}$ \\
$\left(\right.$ day $\left.^{-1}\right)$ & $p \mathrm{CO}_{2}\left(10^{\circ} \mathrm{C}\right)$ & 4 & -0.882 & 0.403 \\
& $p \mathrm{CO}_{2}\left(15^{\circ} \mathrm{C}\right)$ & 4 & 0.601 & 0.564 \\
\hline Maximum nanophytoplankton abundance & $\mathrm{Temperature}^{6}$ & 8 & 1.380 & 0.205 \\
$\left(\times 10^{6}\right.$ cells $\left.\mathrm{L}^{-1}\right)$ & $p \mathrm{CO}_{2}$ & 8 & -0.735 & 0.484 \\
& $p \mathrm{CO}_{2} \times$ temperature & 8 & 0.302 & 0.770 \\
\hline
\end{tabular}


Table 4. Results of the generalized least squares models (gls) tests for the effects of temperature, $p \mathrm{CO}_{2}$, and their interaction during Phase II (day after maximum $\mathrm{Chl} a$ to day 13). Separate analyses with $p \mathrm{CO}_{2}$ as a continuous factor were performed when temperature had a significant effect. Chl $a$ concentration, nanophytoplankton abundance, picoeukaryote abundance, picocyanobacteria abundance, particulate and dissolved primary production, and Chl $a$-normalized particulate and dissolved primary production. Significant results are in bold.

\begin{tabular}{|c|c|c|c|c|}
\hline Response variable & Factor & df & $t$-value & $p$-value \\
\hline \multirow{3}{*}{$\begin{array}{l}\text { Mean Chl } a \text { concentration } \\
\left(\mu \mathrm{g} \mathrm{L}^{-1}\right)\end{array}$} & Temperature & 8 & -1.539 & 0.162 \\
\hline & $p \mathrm{CO}_{2}$ & 8 & 0.733 & 0.484 \\
\hline & $p \mathrm{CO}_{2} \times$ temperature & 8 & 0.156 & 0.880 \\
\hline \multirow{3}{*}{$\begin{array}{l}\text { Mean nanophytoplankton abundance } \\
\left(\times 10^{6} \text { cells } L^{-1}\right)\end{array}$} & Temperature & 8 & -0.528 & 0.612 \\
\hline & $p \mathrm{CO}_{2}$ & 8 & 1.264 & 0.242 \\
\hline & $p \mathrm{CO}_{2} \times$ temperature & 8 & 0.699 & 0.505 \\
\hline \multirow{3}{*}{$\begin{array}{l}\text { Mean picoeukaryote abundance } \\
\left(\times 10^{6} \text { cells } \mathrm{L}^{-1}\right)\end{array}$} & Temperature & 8 & 1.628 & 0.142 \\
\hline & $p \mathrm{CO}_{2}$ & 8 & 0.226 & 0.827 \\
\hline & $p \mathrm{CO}_{2} \times$ temperature & 8 & -0.521 & 0.617 \\
\hline \multirow{3}{*}{$\begin{array}{l}\text { Mean picocyanobacteria abundance } \\
\left(\times 10^{6} \text { cells } \mathrm{L}^{-1}\right)\end{array}$} & Temperature & 8 & 5.983 & $<0.001$ \\
\hline & $p \mathrm{CO}_{2}\left(10^{\circ} \mathrm{C}\right)$ & 4 & 1.480 & 0.213 \\
\hline & $p \mathrm{CO}_{2}\left(15^{\circ} \mathrm{C}\right)$ & 4 & -3.051 & $\mathbf{0 . 0 3 8}$ \\
\hline \multirow{3}{*}{$\begin{array}{l}\text { Particulate primary production } \\
\left(\mu \mathrm{mol} \mathrm{C} \mathrm{L}{ }^{-1}\right)\end{array}$} & Temperature & 8 & -0.015 & 0.988 \\
\hline & $p \mathrm{CO}_{2}$ & 8 & -0.940 & 0.375 \\
\hline & $p \mathrm{CO}_{2} \times$ temperature & 8 & 0.460 & 0.658 \\
\hline \multirow{3}{*}{$\begin{array}{l}\text { Dissolved primary production } \\
(\mu \mathrm{mol} \mathrm{C} \mathrm{L}-1)\end{array}$} & Temperature & 8 & 1.894 & 0.095 \\
\hline & $p \mathrm{CO}_{2}$ & 8 & -1.145 & 0.285 \\
\hline & $p \mathrm{CO}_{2} \times$ temperature & 8 & 0.847 & 0.422 \\
\hline \multirow{3}{*}{$\begin{array}{l}\text { (Log) Chl } a \text {-normalized particulate primary production } \\
\left(\mu \mathrm{mol} C(\mu \mathrm{g} \mathrm{Chl} a)^{-1} \mathrm{~d}^{-1}\right)\end{array}$} & Temperature & 8 & -2.288 & 0.052 \\
\hline & $p \mathrm{CO}_{2}$ & 8 & -1.491 & 0.174 \\
\hline & $p \mathrm{CO}_{2} \times$ temperature & 8 & 1.105 & 0.301 \\
\hline \multirow{3}{*}{$\begin{array}{l}\text { (Log) Chl } a \text {-normalized dissolved primary production } \\
\left(\mu \mathrm{mol} \mathrm{C}(\mu \mathrm{g} \mathrm{Chl} a)^{-1} \mathrm{~d}^{-1}\right)\end{array}$} & Temperature & 8 & 2.357 & 0.046 \\
\hline & $p \mathrm{CO}_{2}\left(10^{\circ} \mathrm{C}\right)$ & 4 & -2.573 & 0.062 \\
\hline & $p \mathrm{CO}_{2}\left(15^{\circ} \mathrm{C}\right)$ & 4 & 1.345 & 0.250 \\
\hline
\end{tabular}

cell counts in all mesocosms at the end of the experiment carried out at $10^{\circ} \mathrm{C}$. At $15^{\circ} \mathrm{C}$, the composition of the assemblage had shifted toward a dominance of unidentified flagellates and choanoflagellates $(2-20 \mu \mathrm{m})$ in all mesocosms, with these two groups accounting for $55-80 \%$ of the total cell counts, while diatoms showed signs of loss of viability as indicated by the presence of empty frustules (Fig. 6b).

\subsection{Primary production}

$P_{\mathrm{P}}$ increased in all mesocosms during Phase I of the experiment, in parallel with the increase in Chl $a$ (Fig. 7a). $P_{\mathrm{P}}$ maxima were attained on days 3-4, except for the $15^{\circ} \mathrm{C}$ Drifter (M11) where $P_{\mathrm{P}}$ peaked on day 1 . We found no significant effect of the $p \mathrm{CO}_{2}$ gradient, temperature, and $p \mathrm{CO}_{2} \times$ temperature interaction on the timeintegrated $P_{\mathrm{P}}$ during both Phases I and II (Fig. 7b, c; Tables 2 and 4). Similarly, the absence of significant treatment effects remained when normalizing $P_{\mathrm{P}}$ per unit of Chl $a$ (Fig. $7 \mathrm{~g}, \mathrm{~h}, \mathrm{i}$ ). Initial $\mathrm{Chl} a$-normalized $P_{\mathrm{P}}$ val- ues were $3.3 \pm 0.5 \mu \mathrm{molC}(\mu \mathrm{g} \mathrm{Chl} a)^{-1} \mathrm{~d}^{-1}$ and reached maxima between $3.7 \pm 0.3 \mu \mathrm{molC}(\mu \mathrm{g} \mathrm{Chl} a)^{-1} \mathrm{~d}^{-1}$ and $5.7 \pm 0.6 \mu \mathrm{mol} \mathrm{C}(\mu \mathrm{g} \mathrm{Chl} a)^{-1} \mathrm{~d}^{-1}$ at 10 and $15^{\circ} \mathrm{C}$, respectively. These values then decreased to $2.2 \pm 0.6 \mu \mathrm{molC}$ $(\mu \mathrm{g} \mathrm{Chl} a)^{-1} \mathrm{~d}^{-1}$ and $0.9 \pm 0.2 \mu \mathrm{molC}(\mu \mathrm{g} \mathrm{Chl} a)^{-1} \mathrm{~d}^{-1}$ on the last day of the experiment. During Phase I, the mean Chl $a$-normalized $P_{\mathrm{P}}$ was not significantly affected by the $p \mathrm{CO}_{2}$ gradient or warming, as observed for the mean $\mathrm{Chl} a$ concentrations and time-integrated $P_{\mathrm{P}}$ over that phase (Fig. 7h; Table 2). During Phase II, the log of the mean Chl $a$ normalized $P_{\mathrm{P}}$ was not significantly affected by the $p \mathrm{CO}_{2}$ gradient, the temperature, or the interaction of these factors (Fig. 7i; Table 4).

$P_{\mathrm{D}}$ was low at the beginning of the experiment, averaging $\quad 1.5 \pm 0.4 \mu \mathrm{molCL} \mathrm{L}^{-1} \mathrm{~d}^{-1}$, increased progressively during Phase $\mathrm{I}$ to reach maximum values of 6-48 $\mu \mathrm{mol} \mathrm{C} \mathrm{L}{ }^{-1} \mathrm{~d}^{-1}$ between days 4 and 8 , and decreased thereafter (Fig. 7d). Time-integrated $P_{\mathrm{D}}$ was not significantly affected by the $p \mathrm{CO}_{2}$ gradient, the temperature, and the $p \mathrm{CO}_{2} \times$ temperature interaction 


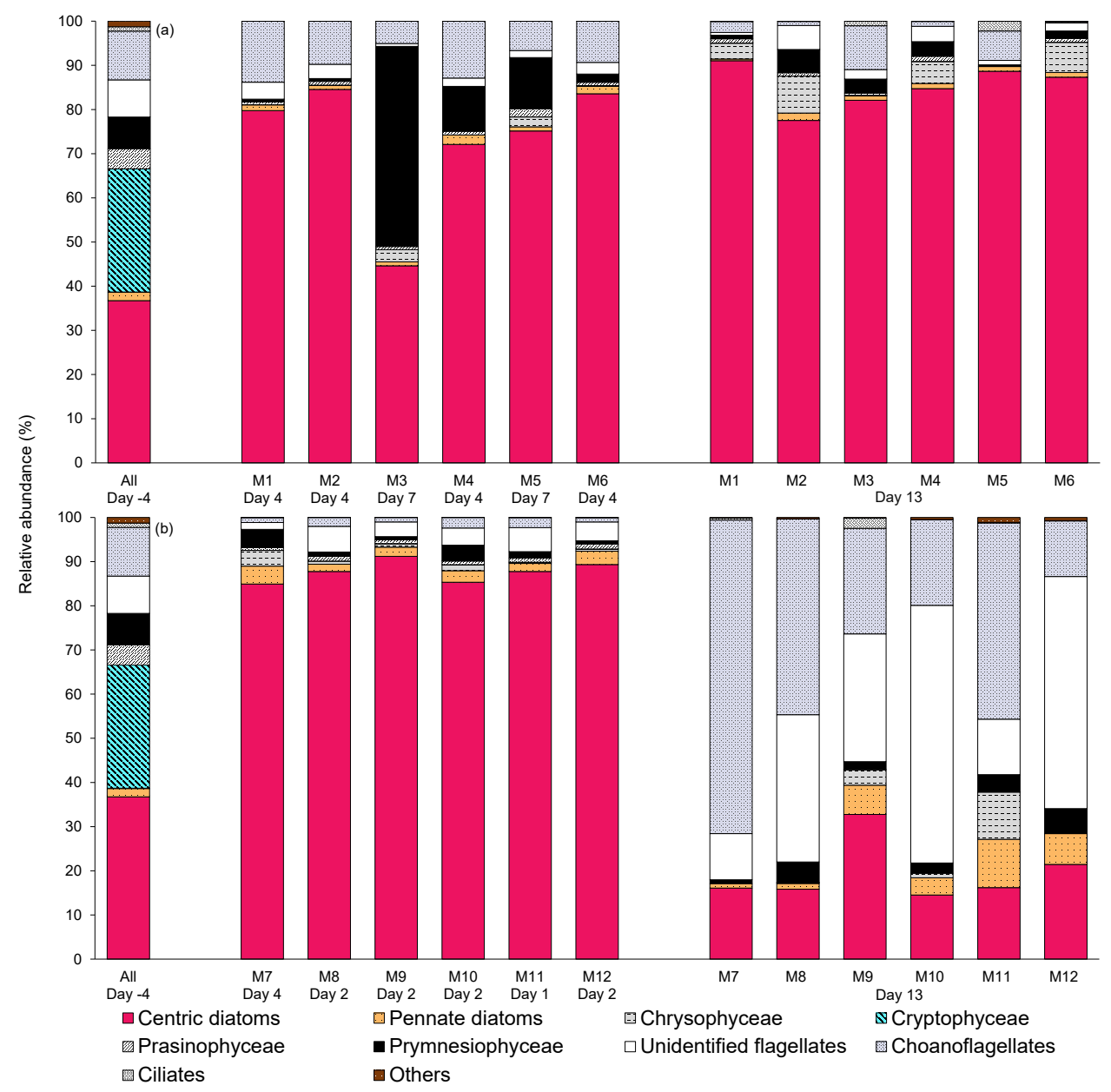

Figure 6. Relative abundance of 10 groups of protists at the beginning of the experiment (day -4 ), on the day of maximum Chl $a$ concentrations in each mesocosm, and at the end of the experiment (day 13) for (a) $10^{\circ} \mathrm{C}$ and (b) $15^{\circ} \mathrm{C}$ mesocosms. The group "others" includes dinoflagellates, Chlorophyceae, Dictyochophyecae, Euglenophyceae, heterotrophic groups, and unidentified cells. Each bar plot represents a mesocosm at a given time. The bar plot on day -4 represents the initial community assemblage before temperature manipulation and acidification, and is therefore the same for each temperature treatment. For symbol attribution to treatments, see legend.

during the two phases (Fig. 7e, f; Tables 2 and 4). Chl $a$-normalized $P_{\mathrm{D}}$ was low on day 0 , averaging $0.3 \pm 0.1 \mu \mathrm{molC}(\mu \mathrm{g} \mathrm{Chl} a)^{-1} \mathrm{~d}^{-1}$, reached maximum values of $1.0 \pm 0.2 \mu \mathrm{molC}(\mu \mathrm{g} \mathrm{Chl} a)^{-1} \mathrm{~d}^{-1}$ and $1.6 \pm$ $0.2 \mu \mathrm{molC}(\mu \mathrm{g} \mathrm{Chl} a)^{-1} \mathrm{~d}^{-1}$ at 10 and $15^{\circ} \mathrm{C}$, and then, respectively, decreased to $0.17 \pm 0.05 \mu \mathrm{mol} \mathrm{C}(\mu \mathrm{g} \mathrm{Chl} a)^{-1} \mathrm{~d}^{-1}$ and $0.6 \pm 0.2 \mu \mathrm{molC}(\mu \mathrm{g} \mathrm{Chl} a)^{-1} \mathrm{~d}^{-1}$ by the end of the experiment (Fig. 7j). During Phase I, the mean Chl $a$ normalized $P_{\mathrm{D}}$ was affected by neither the $p \mathrm{CO}_{2}$ gradient, nor the temperature, nor the interaction between those factors (Fig. 7k; Table 2). During Phase II, the log of the mean Chl $a$-normalized $P_{\mathrm{D}}$ was not affected by $p \mathrm{CO}_{2}$ at either temperature tested, but significantly increased with warming (Fig. 71; Table 4).

Figure 6 shows the influence of the treatments on maximum $P_{\mathrm{P}}$ and $P_{\mathrm{D}}$ as well as on the time-integrated $P_{\mathrm{P}}$ and $P_{\mathrm{D}}$ over the full length of the experiment. We found no effect of the $p \mathrm{CO}_{2}$ gradient on the maximum $P_{\mathrm{P}}$ values at the two temperatures tested, but warming increased the maximum $P_{\mathrm{P}}$ values from $66 \pm 13 \mu \mathrm{molC} \mathrm{C}^{-1} \mathrm{~d}^{-1}$ to $126 \pm$ $8 \mu \mathrm{mol} \mathrm{CL}{ }^{-1} \mathrm{~d}^{-1}$ (Fig. 8a; Table 5). The time-integrated $P_{\mathrm{P}}$ over the full duration of the experiment was not affected by the $p \mathrm{CO}_{2}$ gradient or the increase in temperature (Fig. 8b; Table 5). The maximum $P_{\mathrm{D}}$ values were significantly affected by the treatments (Fig. 8c; Table 5). Maximum $P_{\mathrm{D}}$ decreased with increasing $p \mathrm{CO}_{2}$ at in situ temperature, but warming cancelled this effect (antagonistic effect). Nevertheless, the time-integrated $P_{\mathrm{D}}$ over the whole experiment did not vary significantly between treatments, although a decreasing tendency with increasing $p \mathrm{CO}_{2}$ at $10^{\circ} \mathrm{C}$ and an increasing tendency with warming can be seen in Fig. 8d (Table 5). 
Table 5. Results of the generalized least squares models (gls) tests for the effects of temperature, $p \mathrm{CO}_{2}$, and their interaction. Separate analyses with $p \mathrm{CO}_{2}$ as a continuous factor were performed when temperature had a significant effect. Maximum particulate and dissolved primary production, and time integration over the full duration of the experiment (day 0 to day 13). Natural logarithm transformation is indicated in parentheses when necessary; significant results are in bold.

\begin{tabular}{|c|c|c|c|c|}
\hline Response variable & Factor & df & $t$-value & $p$-value \\
\hline \multirow{3}{*}{$\begin{array}{l}\text { Maximum particulate primary production } \\
\left(\mu \mathrm{mol} \mathrm{C} \mathrm{L}-1 \mathrm{~d}^{-1}\right)\end{array}$} & Temperature & 8 & 2.466 & 0.039 \\
\hline & $p \mathrm{CO}_{2}\left(10^{\circ} \mathrm{C}\right)$ & 4 & -2.328 & 0.080 \\
\hline & $p \mathrm{CO}_{2}\left(15^{\circ} \mathrm{C}\right)$ & 4 & -2.394 & 0.075 \\
\hline \multirow{3}{*}{ 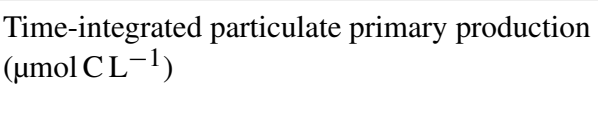 } & Temperature & 8 & -0.055 & 0.958 \\
\hline & $p \mathrm{CO}_{2}\left(10^{\circ} \mathrm{C}\right)$ & 4 & -1.300 & 0.230 \\
\hline & $p \mathrm{CO}_{2}\left(15^{\circ} \mathrm{C}\right)$ & 4 & 0.801 & 0.446 \\
\hline \multirow{3}{*}{$\begin{array}{l}\text { (Log) Maximum dissolved primary production } \\
\left(\mu \mathrm{mol} \mathrm{C} \mathrm{L} \mathrm{L}^{-1} \mathrm{~d}^{-1}\right)\end{array}$} & Temperature & 8 & -0.659 & 0.528 \\
\hline & $p \mathrm{CO}_{2}$ & 8 & -3.342 & 0.010 \\
\hline & $p \mathrm{CO}_{2} \times$ temperature & 8 & 2.858 & 0.021 \\
\hline \multirow{3}{*}{$\begin{array}{l}\text { Time-integrated dissolved primary production } \\
\left(\mu \mathrm{mol} \mathrm{CL}^{-1}\right)\end{array}$} & Temperature & 8 & 1.687 & 0.130 \\
\hline & $p \mathrm{CO}_{2}$ & 8 & -2.153 & 0.063 \\
\hline & $p \mathrm{CO}_{2} \times$ temperature & 8 & 1.880 & 0.097 \\
\hline
\end{tabular}

\section{Discussion}

\subsection{General characteristics of the bloom}

The onset of the experiment was marked by an increase in $p \mathrm{CO}_{2}$ on the day following the filling of the mesocosms. This phenomenon often takes place at the beginning of such experiments when pumping tends to break phytoplankton cells and larger debris into smaller ones. We attribute the rapid fluctuations in $p \mathrm{CO}_{2}$ to the release of organic matter following the filling of the mesocosms with a stimulating effect on heterotrophic respiration, and hence $\mathrm{CO}_{2}$ production. Then, a phytoplankton bloom, numerically dominated by the centric diatom $S$. costatum, took place in all mesocosms, regardless of treatments (Fig. 6). S. costatum is a common phytoplankton species in the St. Lawrence Estuary and in coastal waters (Kim et al., 2004; Starr et al., 2004; Annane et al., 2015). The length of the experiment (13 days) allowed us to capture both the development and declining phases of the bloom. The exponential growth phases lasted 1-4 days depending on the treatments, but maximal $\mathrm{Chl} a$ concentrations were reached only after 7 days in 2 of the 12 mesocosms (Fig. 4a; Table 1). The suite of measurements and statistical tests conducted did not provide any clues as to the underlying causes of the lower rates of biomass accumulation measured in these two mesocosms. Since statistical analyses conducted with or without these two apparent outliers gave similar results, they were not excluded from the analyses.

In situ nutrient conditions prior to the water collection were favourable for a bloom development. Based on previous studies, in situ phytoplankton growth was probably limited by light due to water turbidity and vertical mixing at the time of water collection (Levasseur et al., 1984). Grazing may also have played a role in keeping the in situ biomass of flagellates low prior to our sampling. However, a natural diatom fall bloom was observed in the days following the water collection in the adjacent region (Gustavo Ferreyra, personal communication, 2014). The increased stability within the mesocosms, combined with the reduction of the grazing pressure (filtration on $250 \mu \mathrm{m}$ ), likely contributed to the fast accumulation of phytoplankton biomass. During the development phase of the bloom, the concentration of all three monitored nutrients decreased, with $\mathrm{NO}_{3}^{-}$and $\mathrm{Si}(\mathrm{OH})_{4}$ reaching undetectable values. This nutrient co-depletion is consistent with results from previous studies suggesting a co-limitation of diatom blooms by these two nutrients in the St. Lawrence Estuary (Levasseur et al., 1987, 1990). Variations in $P_{\mathrm{P}}$ roughly followed changes in Chl $a$, and, as expected, the maximum Chl $a$-normalized $P_{\mathrm{P}}\left(5 \pm 2 \mu \mathrm{molC}(\mu \mathrm{g} \mathrm{Chl} a)^{-1} \mathrm{~d}^{-1}\right)$ was reached during the exponential growth phase in all mesocosms. Decreases in total phytoplankton abundances and $P_{\mathrm{P}}$ followed the bloom peaks and the timing of the $\mathrm{NO}_{3}^{-}$and $\mathrm{Si}(\mathrm{OH})_{4}$ depletions. A clear succession in phytoplankton size classes characterized the experiment. Nanophytoplankton cells were initially present in low abundance and became more numerous as the $S$. costatum diatom bloom developed. The correlation $\left(r^{2}=0.83, p<0.001, \mathrm{df}=34\right)$ between the abundance of nanophytoplankton and $S$. costatum enumeration suggests that this cell size class can be used as a proxy of $S$. costatum counts in all mesocosms throughout the experiment. Nanophytoplankton cells accounted for $79 \pm 7 \%$ of total counts of cells $<20 \mu \mathrm{m}$ on the day of the maximum $\mathrm{Chl} a$ concentration. Accordingly, nanophytoplankton exhibited the same temporal trend as Chl $a$ concentrations. During Phase II, nanophytoplankton abundances remained roughly stable at in situ temperature, but decreased at $15^{\circ} \mathrm{C}$ towards the end of the experiment. Photosynthetic picoeukaryotes 


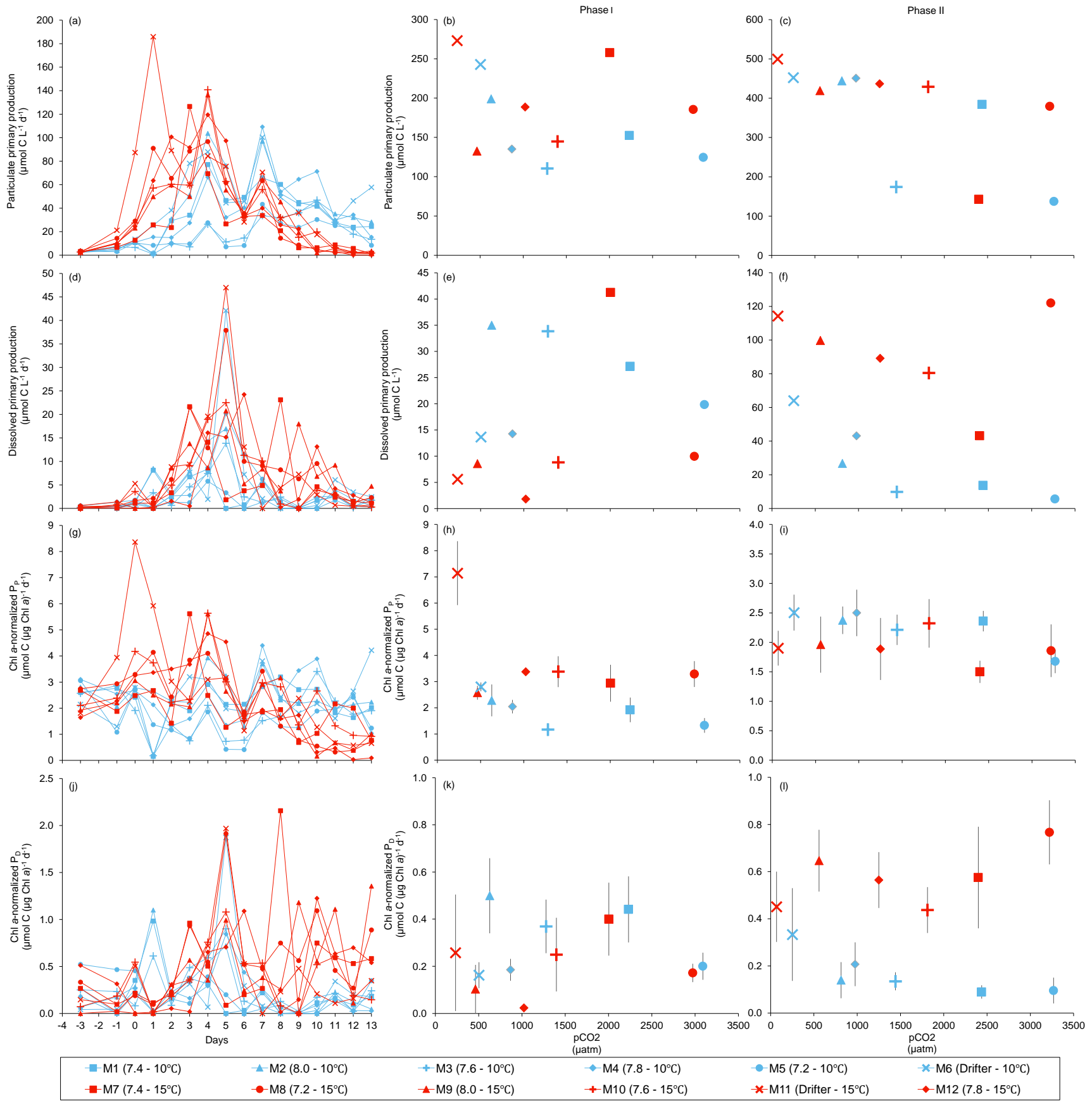

Figure 7. Temporal variations and time-integrated or averaged \pm SE during Phase I (day 0 to day of maximum Chl $a$ concentration) and Phase II (day after maximum Chl $a$ concentration to day 13) for (a-c) particulate primary production, (d-f) dissolved primary production, (g-i) Chl $a$-normalized particulate primary production, and (j-l) $\mathrm{Chl} a$-normalized dissolved primary production. For symbol attribution to treatments, see legend.

were originally abundant and decreased throughout the experiment, whereas picocyanobacteria abundances increased during Phase II. This is a typical phytoplankton succession pattern for temperate systems where an initial diatom bloom growing essentially on allochthonous nitrate gives way to smaller species growing on regenerated forms of nitrogen (Taylor et al., 1993). 


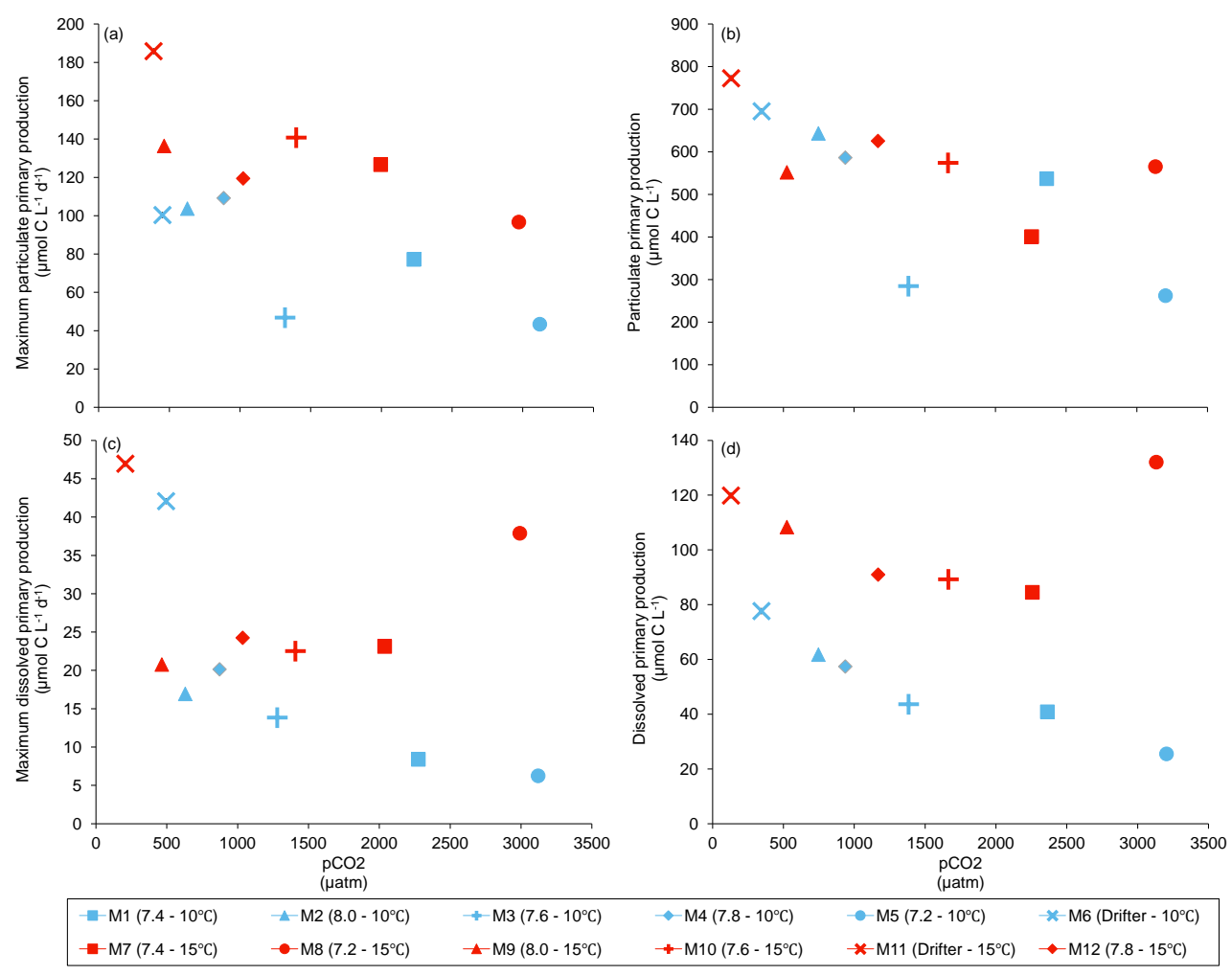

Figure 8. (a) Maximum particulate primary production, (b) time-integrated particulate primary production, (c) maximum dissolved primary production, and (d) time-integrated dissolved primary production over the full course of the experiment (day 0 to day 13). For symbol attribution to treatments, see legend.

\subsection{Phase I (diatom bloom development)}

Our results show no significant effect of increasing $p \mathrm{CO}_{2} /$ decreasing $\mathrm{pH}$ on the mean abundance and net accumulation rate of the diatom-dominated nanophytoplankton assemblage during the development of the bloom (Figs. 4e and 5 c). These results suggest that $S$. costatum, the species accounting for most of the biomass accumulation during the bloom, neither benefited from the higher $p \mathrm{CO}_{2}$ nor was negatively impacted by the lowering of $\mathrm{pH}$. Assuming that $S$. costatum was also responsible for most of the carbon fixation during the bloom development phase, the absence of effect on $P_{\mathrm{P}}$ and $\mathrm{Chl} a$-normalized $P_{\mathrm{P}}$ following increases in $p \mathrm{CO}_{2}$ brings additional support to our conclusion. $S$. costatum operates a highly efficient CCM, minimizing the potential benefits of thriving in high $\mathrm{CO}_{2}$ waters (Trimborn et al., 2009). This may explain why the strain present in the LSLE did not benefit from the higher $p \mathrm{CO}_{2}$ conditions. Likewise, a mesocosm experiment conducted in the coastal North Sea showed no significant effect of increasing $p \mathrm{CO}_{2}$ on carbon fixation during the development of the spring diatom bloom (Eberlein et al., 2017).
In addition to the aforementioned insensitivity to increasing $p \mathrm{CO}_{2}$, our results point towards a strong resistance of $S$. costatum to severe $\mathrm{pH}$ decline. During our study, surprisingly constant rates of $\mathrm{Chl} a$ accumulation and nanophytoplankton growth (Fig. 5a, c), as well as maximum $P_{\mathrm{P}}$ (Fig. 8a), were measured during the development phase of the bloom over a range of $\mathrm{pH}_{\mathrm{T}}$ extending from 8.6 to 7.2 (Fig. 3a). In a recent effort to estimate the causes and amplitudes of short-term variations in $\mathrm{pH}_{\mathrm{T}}$ in the LSLE, Mucci et al. (2018) showed that $\mathrm{pH}_{\mathrm{T}}$ in surface waters was constrained within a range of 7.85 to 7.93 during a $50 \mathrm{~h}$ survey over two tidal cycles at the head of the Laurentian Channel. It is notable that even the upwelling of water from $100 \mathrm{~m}$ depth or of low-oxygen LSLE bottom water would not decrease $\mathrm{pH}_{\mathrm{T}}$ beyond $\sim 7.75$ and $\sim 7.62$, respectively (Mucci et al., 2018, and references therein). Our results show that the phytoplankton assemblage responsible for the fall bloom may tolerate even greater $\mathrm{pH}_{\mathrm{T}}$ excursions. In the LSLE, such conditions may arise when the contribution of the low $\mathrm{pH}_{\mathrm{T}}$ (7.12) freshwaters of the Saguenay River to the LSLE surface waters is amplified during the spring freshet. However, considering that comparable studies conducted in different environments have reported negative effects of decreasing $\mathrm{pH}$ on diatom biomass accumulation 
(Hare et al., 2007; Hopkins et al., 2010; Schulz et al., 2013), it cannot be concluded that all diatom species thriving in the LSLE are insensitive to acidification.

In contrast to the $p \mathrm{CO}_{2}$ treatment, warming affected the development of the bloom in several ways. Increasing temperature by $5^{\circ} \mathrm{C}$ significantly increased the accumulation rate of Chl $a$ and the nanophytoplankton growth rate during Phase I of the bloom. The positive effects of warming on maximum $P_{\mathrm{P}}$ during the development phase of the bloom most likely reflect the sensitivity of photosynthesis to temperature (Sommer and Lengfellner, 2008; Kim et al., 2013). It could also be related to optimal growth temperatures, which are often higher than in situ temperatures in marine phytoplankton (Thomas et al., 2012; Boyd et al., 2013). In support of this hypothesis, previous studies have reported optimal growth temperatures of $20-25^{\circ} \mathrm{C}$ for $S$. costatum, which is $5-10^{\circ} \mathrm{C}$ higher than the warmer treatment investigated in our study (Suzuki and Takahashi, 1995; Montagnes and Franklin, 2001). Extrapolating results from a mesocosm experiment to the field is not straightforward, as little is known of the projected warming of the upper waters of the LSLE in the next decades. In the Gulf of St. Lawrence, positive temperature anomalies in surface waters have varied from 0.25 to $0.75{ }^{\circ} \mathrm{C}$ per decade between 1985 and 2013 (Larouche and Galbraith, 2016). In the LSLE, warming of surface waters will likely result from a complex interplay between heat transfer at the air-water interface and variations in vertical mixing and upwelling of the cold intermediate layer at the head of the estuary (Galbraith et al., 2014). Considering current uncertainties regarding future warming of the LSLE, studies should be conducted over a wider range of temperatures in order to better constrain the potential effect of warming on the development of the blooms in the LSLE.

Picoeukaryotes showed a more or less gradual decrease in abundance during Phase I, and our results show that this decline was not influenced by the increases in $p \mathrm{CO}_{2}$ (Fig. $4 \mathrm{~g}$, $\mathrm{h}$; Table 2). Picoeukaryotes are expected to benefit from high $p \mathrm{CO}_{2}$ conditions even more so than diatoms as $\mathrm{CO}_{2}$ can passively diffuse through their relatively thin boundary layer, precluding the necessity of a costly uptake mechanism such as a CCM (Schulz et al., 2013). This hypothesis has been supported by several studies showing a stimulating effect of $p \mathrm{CO}_{2}$ on picoeukaryote growth (Bach et al., 2016; Hama et al., 2016; Schulz et al., 2017, and references therein). On the other hand, in nature, the abundance of picoeukaryotes generally results from a delicate balance between cell division rates and cell losses through microzooplankton grazing and viral attacks. The few experiments, including the current study, reporting the absence or a modest effect of increasing $p \mathrm{CO}_{2}$ on the abundance of eukaryotic picoplankton attribute their observations to an increase in nano- and microzooplankton grazing (Rose et al., 2009; Neale et al., 2014). During our experiment, the biomass of microzooplankton increased with increasing $p \mathrm{CO}_{2}$ by ca. $200-300 \%$ at the two temperatures tested (Gustavo Ferreyra and Mohamed Lem- lih, unpublished data). Thus, it is possible that a positive effect of increasing $p \mathrm{CO}_{2}$ and warming on picoeukaryote abundances might have been masked by higher picoeukaryote losses due to increased microzooplankton grazing.

\subsection{Phase II (declining phase of the bloom)}

The gradual decrease in nanophytoplankton abundances coincided with an increase in the abundance of picocyanobacteria (Fig. 4j). At in situ temperature, the picocyanobacteria abundance during Phase II was unaffected by the increase in $p \mathrm{CO}_{2}$ over the full range investigated (Fig. 4l; Table 4). The lack of a positive response of picocyanobacteria to elevated $p \mathrm{CO}_{2}$ was somewhat surprising considering that they have less efficient CCMs than diatoms (Schulz et al., 2013). Accordingly, several studies have reported a stimulation of the net growth rate of picocyanobacteria under elevated $p \mathrm{CO}_{2}$ in different environments (coastal Japan, Mediterranean Sea, and Raunejforden in Norway) and under different nutrient regimes, i.e. bloom and post-bloom conditions (Hama et al., 2016; Sala et al., 2016; Schulz et al., 2017). However, studies have also shown no direct effect of elevated $p \mathrm{CO}_{2}$ on the net growth of picocyanobacteria during studies conducted in the subtropical North Atlantic and the South Pacific (Law et al., 2012; Lomas et al., 2012). In our study, picocyanobacteria abundance was even reduced when high $\mathrm{CO}_{2}$ was combined with warming. Similar negative effects of $\mathrm{CO}_{2}$ on picocyanobacteria (particularly Synechococcus) have also been observed under later stages of bloom development, i.e. nutrient depletion, caused by either competition or grazing (Paulino et al., 2008; Hopkins et al., 2010). A potential increase in grazing pressure, following the rise in heterotrophic nanoflagellate abundance (e.g. choanoflagellates; Fig. 6b) measured under high $p \mathrm{CO}_{2}$ and warmer conditions, could explain the ostensible negative effect of increasing $p \mathrm{CO}_{2}$ on picocyanobacteria abundance in our experiment. Despite the absence of grazing measurements during our study, our results support the hypothesis that the potential for increased picocyanobacteria population growth under elevated $p \mathrm{CO}_{2}$ and temperature is partially dependent on different grazing pressures (Fu et al., 2007).

Neither warming nor acidification affected the net particulate carbon fixation during the declining phase of the bloom. In our study, the time-integrated $P_{\mathrm{P}}$ and $\mathrm{Chl} a$-normalized $P_{\mathrm{P}}$ were not significantly affected by the increase in $p \mathrm{CO}_{2}$ during Phase II at the two temperatures tested (Fig. 7; Table 4). This result is surprising since nitrogen-limited cells have been shown to be more sensitive to acidification, resulting in a reduction in carbon fixation rates due to higher respiration (Wu et al., 2010; Gao and Campbell, 2014; Raven et al., 2014). Although our measurements do not allow us to discriminate between the contributions of the different phytoplankton size classes to carbon fixation, we can speculate that diatoms, which were still abundant during Phase II, contributed a significant fraction of the primary produc- 
tion. If so, these results suggest that $S$. costatum remained insensitive to $\mathrm{OA}$ even under nutrient stress. However, in contrast to Phase I, increasing the temperature by $5^{\circ} \mathrm{C}$ during Phase II significantly increased the $\mathrm{Chl} a$-normalized $P_{\mathrm{D}}$. The warming-induced increase in fixed carbon being released in the dissolved fraction likely stems from increased exudation by phytoplankton, or sloppy feeding/excretion following ingestion by grazers (Kim et al., 2011). The increase in fixed carbon released as dissolved organic carbon (DOC) measured during Phase II may also result from greater respiration by the nitrogen-limited diatoms during periods of darkness of the incubations, as dark phytoplankton respiration rates generally increase with temperature (Butrón et al., 2009; Robarts and Zohary, 1987). Moreover, the enclosures do not permit the sinking and export of particulate organic carbon (POC), allowing a further transformation into DOC by heterotrophic bacteria, a process that could be exacerbated under warming (Wohlers et al., 2009).

\subsection{Effect of the treatments on primary production over the full experiment}

As mentioned above, increasing $p \mathrm{CO}_{2}$ had no effect on timeintegrated $P_{\mathrm{P}}$ during the two phases of the bloom, and warming only affected the maximum $P_{\mathrm{P}}$. As a result, primary production rates integrated over the whole duration of the experiment were not significantly different between the two temperatures tested. Although not statistically significant, the time-integrated $P_{\mathrm{D}}$ over the full experiment displays a slight decrease with increasing $p \mathrm{CO}_{2}$ at $10^{\circ} \mathrm{C}$ and overall higher values in the warmer treatment (Fig. 8d; Table 5). Previous studies have reported increases in DOC exudation (Engel et al., 2013), but also decreasing DOC concentrations at elevated $p \mathrm{CO}_{2}$ under nitrate limitation (Yoshimura et al., 2014). The increase in DOC exudation is attributed to a stimulation of photosynthesis resulting from its sensitivity to higher $p \mathrm{CO}_{2}$ (Engel et al., 2013), but the causes of a decrease in DOC concentrations at high $p \mathrm{CO}_{2}$ are less clear and potentially attributable to an increase in transparent exopolymer particle (TEP) production (Yoshimura et al., 2014). Elevated TEP production under high $p \mathrm{CO}_{2}$ conditions has been measured at both the peak of a bloom in a mesocosm study (Engel et al., 2014) and in post-bloom nutrient-depleted conditions (MacGilchrist et al., 2014). However, during our study, TEP production decreased under high $p \mathrm{CO}_{2}$ (Gaaloul, 2017). Thus, the apparent decrease in $P_{\mathrm{D}}$ cannot be attributed to a greater conversion of exuded dissolved carbohydrate into TEP. The apparent rise in $P_{\mathrm{D}}$ under warming is consistent with previous studies reporting similar increases in phytoplankton dissolved carbon release with temperature (Morán et al., 2006; Engel et al., 2011). Although these apparent changes in $P_{\mathrm{D}}$ with increasing $p \mathrm{CO}_{2}$ and warming require further investigations, they suggest that a larger proportion ( $\sim 15 \%$ of $P_{\mathrm{T}}$ at $15^{\circ} \mathrm{C}$ compared to $10 \%$ at $10^{\circ} \mathrm{C}$ ) of the newly fixed carbon could be exuded and become available for heterotrophic organisms under warmer conditions.

\subsection{Implications and limitations}

During our study, we chose to keep the $\mathrm{pH}$ constant during the whole experiment instead of allowing it to vary with changes in photosynthesis and respiration during the bloom phases. This approach differs from previous mesocosm experiments where generally no subsequent $\mathrm{CO}_{2}$ manipulations are conducted after the initial targets are attained (Schulz et al., 2017, and references therein). Keeping the $\mathrm{pH}$ and $p \mathrm{CO}_{2}$ conditions stable during our study allowed us to precisely quantify the effect of the changing $\mathrm{pH} / p \mathrm{CO}_{2}$ on the processes taking place during the different phases of the bloom. Such control was not exercised in two of our mesocosms (i.e. the Drifters). In these two mesocosms, the $\mathrm{pH}_{\mathrm{T}}$ increased from 7.9 to 8.3 at $10^{\circ} \mathrm{C}$, and from 7.9 to 8.7 at $15^{\circ} \mathrm{C}$. Since the buffer capacity of acidified waters diminishes with increasing $\mathrm{CO}_{2}$, the drift in $p \mathrm{CO}_{2}$ and $\mathrm{pH}$ due to biological activity would have been even greater in the more acidified treatments (Delille et al., 2005; Riebesell et al., 2007). Hence, allowing the $\mathrm{pH}$ to drift in all mesocosms would have likely ended in an overlapping of the treatments where acidification effects would have been harder to detect. Thus, our experiment could be considered an intermediate one between strictly controlled small-scale laboratory experiments and large-scale pelagic mesocosm experiments in which only the initial conditions are set. By limiting $p \mathrm{CO}_{2}$ decrease under high $\mathrm{CO}_{2}$ drawdown due to photosynthesis during the development of the bloom phase, we minimise confounding effects of $p \mathrm{CO}_{2}$ potentially overlapping in association with high biological activity in the mesocosms. Hence, the experimental conditions could be considered extreme examples of acidification conditions, due to the extent of $p \mathrm{CO}_{2}$ values studied. However, the absence of OA effects on most biological parameters measured during our study, even under these extreme conditions, strengthens the argument that the phytoplankton community in LSLE is resistant to OA.

\section{Conclusion}

Our results reveal a remarkable resistance of the different phytoplankton size classes to the large range of $p \mathrm{CO}_{2} / \mathrm{pH}$ investigated during our study. It is noteworthy that the plankton assemblage was subjected to decreases in $\mathrm{pH}$ far exceeding those that they are regularly exposed to in the LSLE. The resistance of $S$. costatum to the $p \mathrm{CO}_{2}$ treatments suggests that the acidification of surface waters of the LSLE will not affect the development rate and the amplitude of fall blooms dominated by this species. Photosynthetic picoeukaryotes and picocyanobacteria thriving alongside the blooming diatoms were also insensitive to acidification. In contrast to the $p \mathrm{CO}_{2}$ treatments, warming the water by $5^{\circ} \mathrm{C}$ had mul- 
tiple impacts on the development and decline of the bloom. The $5^{\circ} \mathrm{C}$ warming hastened the development of the diatom bloom (albeit with no increase in total cell number) and increased the abundance of picocyanobacteria during Phase II despite a reduction under high $p \mathrm{CO}_{2}$. These temperatureinduced variations in the phytoplankton assemblage were accompanied by an increase in maximal $P_{\mathrm{P}}$ and suggest a potential increase in $P_{\mathrm{D}}$ under warming, although no significant changes in time-integrated $P_{\mathrm{P}}$ and $P_{\mathrm{D}}$ were observed over the phases or the full temporal scale of the experiment. Overall, our results indicate that warming could have more important impacts than acidification on phytoplankton bloom development in the LSLE in the next decades. Future studies should be conducted and specifically designed to better constrain the potential effects of warming on phytoplankton succession and primary production in the LSLE.

Data availability. The data are freely accessible via https://doi.org/10.1594/PANGAEA.886887 (Bénard et al., 2018), or can be obtained by contacting the author (robin.benard.1@ulaval.ca).

Author contributions. RB was responsible for the experimental design elaboration, data sampling and processing, and redaction of this article. Several coauthors supplied specific data for this article, including carbonate chemistry data provided by AM, inorganic nutrient data from MAB and JÉT, and picophytoplankton and nanophytoplankton cell counts from MS. All co-authors contributed to the final version of this article.

Competing interests. The authors declare that they have no conflict of interest.

Acknowledgements. The authors wish to thank Station Aquicole ISMER, especially Nathalie Morin and her staff, for their support during the project. We also wish to acknowledge Gilles Desmeules, Bruno Cayouette, Sylvain Blondeau, Claire Lix, Rachel Hussherr, Liliane St-Amand, Marjolaine Blais, Armelle Simo, and Sonia Michaud for their help in setting up, sampling, and processing samples during the experiment. The authors want to thank JeanPierre Gattuso for his constructive comments on an earlier draft of the manuscript. This study was funded by a Team grant from the Fonds de la Recherche du Québec - Nature et Technologies (FRQNT-Équipe-165335), the Canada Foundation for Innovation, and the Canada Research Chair on Ocean Biogeochemistry and Climate. This is a contribution to the research programme of Québec-Océan.

Edited by: Katja Fennel

Reviewed by: two anonymous referees

\section{References}

Annane, S., St-Amand, L., Starr, M., Pelletier, E., and Ferreyra, G. A.: Contribution of transparent exopolymeric particles (TEP) to estuarine particulate organic carbon pool, Mar. Ecol.-Prog. Ser., 529, 17-34, https://doi.org/10.3354/meps11294, 2015.

Bach, L. T., Taucher, J., Boxhammer, T., Ludwig, A., AberleMalzahn, N., Abrahamsson, K., Almén, A. K., Asplund, M. E., Audritz, S., Boersma, M., Breitbarth, E., Bridges, C., Brussaard, C., Brutemark, A., Clemmesen, C., Collins, S., Crawfurd, K., Dahlke, F., Deckelnick, M., Dittmar, T., Doose, R., Dupont, S., Eberlein, T., Endres, S., Engel, A., Engström-Öst, J., Febiri, S., Fleischer, D., Fritsche, P., Gledhill, M., Göttler, G., Granberg, M., Grossart, H. P., Grifos, A., Hoffmann, L., Karlsson, A., Klages, M., John, U., Jutfelt, F., Köster, I., Lange, J., Leo, E., Lischka, S., Lohbeck, K., Lundve, B., Mark, F. C., Meyerhöfer, M., Nicolai, M., Pansch, C., Petersson, B., Reusch, T., De Moraes, K. R., Schartau, M., Scheinin, M., Schulz, K. G., Schwarz, U., Stenegren, M., Stiasny, M., Storch, D., Stuhr, A., Sswat, L., Svensson, M., Thor, P., Voss, M., Van De Waal, D., Wannicke, N., Wohlrab, S., Wulff, A., Achterberg, E. P., Algueró-Muñiz, M., Anderson, L. G., Bellworthy, J., Büdenbender, J., Czerny, J., Ericson, Y., Esposito, M., Fischer, M., Haunost, M., Hellemann, D., Horn, H. G., Hornick, T., Meyer, J., Sswat, M., Zark, M., and Riebesell, U.: Influence of ocean acidification on a natural winter-to-summer plankton succession: First insights from a long-term mesocosm study draw attention to periods of low nutrient concentrations, PLoS ONE, 11, 1-33, https://doi.org/10.1371/journal.pone.0159068, 2016.

Beardall, J., Stojkovic, S., and Gao, K.: Interactive effects of nutrient supply and other environmental factors on the sensitivity of marine primary producers to ultraviolet radiation: Implications for the impacts of global change, Aquat. Biol., 22, 5-23, https://doi.org/10.3354/ab00582, 2014.

Bénard, R., Levasseur, M., Scarratt, M. G., Blais, M.-A., Mucci, A., Ferreyra, G. A., Starr, M., Gosselin, M., Tremblay, J.-É., and Lizotte, M.: Experimental assessment of the St. Lawrence Estuary phytoplankton fall bloom sensitivity to acidification and warming, PANGAEA, https://doi.org/10.1594/PANGAEA.886887, 2018.

Bérard-Therriault, L., Poulin, M., and Bossé, L.: Guide d'identification du phytoplancton marin de l'estuaire et du golfe du Saint-Laurent incluant également certains protozoaires, Canadian Special Publication of Fisheries and Aquatic Sciences, 128, 1-387, 1999.

Boyd, P. W. and Hutchins, D. A.: Understanding the responses of ocean biota to a complex matrix of cumulative anthropogenic change, Mar. Ecol.-Prog. Ser., 470, 125-135, https://doi.org/10.3354/meps10121, 2012.

Boyd, P. W., Rynearson, T. A., Armstrong, E. A., Fu, F., Hayashi, K., Hu, Z., Hutchins, D. A., Kudela, R. M., Litchman, E., Mulholland, M. R., Passow, U., Strzepek, R. F., Whittaker, K. A., Yu, E., and Thomas, M. K.: Marine Phytoplankton temperature versus growth responses from polar to tropical waters outcome of a scientific community-wide study, PLoS ONE, 8, https://doi.org/10.1371/journal.pone.0063091, 2013.

Boyd, P. W., Lennartz, S. T., Glover, D. M., and Doney, S. C.: Biological ramifications of climate-change-mediated oceanic multi-stressors, Nat. Clim. Change, 5, 71-79, https://doi.org/10.1038/nclimate2441, 2015. 
Brussaard, C. P. D., Noordeloos, A. A. M., Witte, H., Collenteur, M. C. J., Schulz, K., Ludwig, A., and Riebesell, U.: Arctic microbial community dynamics influenced by elevated $\mathrm{CO}_{2}$ levels, Biogeosciences, 10, 719-731, https://doi.org/10.5194/bg-10719-2013, 2013.

Butrón, A., Iriarte, A., and Madariaga, I.: Size-fractionated phytoplankton biomass, primary production and respiration in the Nervión-Ibaizabal estuary: A comparison with other nearshore coastal and estuarine ecosystems from the Bay of Biscay, Cont. Shelf Res., 29, 1088-1102, https://doi.org/10.1016/j.csr.2008.11.013, 2009.

Byrne, R. H.: Standardization of Standard Buffers by Visible Spectrometry, Anal. Chem, 59, 1479-1481, https://doi.org/10.1021/ac00137a025, 1987.

Cai, W. J. and Wang, Y.: The chemistry, fluxes, and sources of carbon dioxide in the estuarine waters of the Satilla and Altamaha Rivers, Georgia, Limnol. Oceanogr., 43, 657-668, https://doi.org/10.4319/lo.1998.43.4.0657, 1998.

Caldeira, K. and Wickett, M. E.: Ocean model predictions of chemistry changes from carbon dioxide emissions to the atmosphere and ocean, J. Geophys. Res., 110, 1-12, https://doi.org/10.1029/2004JC002671, 2005.

Clayton, T. D. and Byrne, R. H.: Spectrophotometric seawater $\mathrm{pH}$ measurements: total hydrogen ion concentration scale calibration of m-cresol purple and at-sea results, Deep-Sea Res. Pt. I, 40, 2115-2129, https://doi.org/10.1016/0967-0637(93)90048-8, 1993

d'Anglejan, B.: Recent sediments and sediment transport processes in the St. Lawrence Estuary, in: Oceanography of a large-scale estuarine system, edited by: El-Sabh, M. I. and Silverberg, N., Springer-Verlag, New York, USA, 109-129, https://doi.org/10.1007/978-1-4615-7534-4_6, 1990.

Delille, B., Harlay, J., Zondervan, I., Jacquet, S., Chou, L., Wollast, R., Bellerby, R. G. J., Frankignoulle, M., Borges, A. V., Riebesell, U., and Gattuso, J. P.: Response of primary production and calcification to changes of $p \mathrm{CO}_{2}$ during experimental blooms of the coccolithophorid Emiliania huxleyi, Global Biogeochem. Cy., 19, 1-14, https://doi.org/10.1029/2004GB002318, 2005.

Dickson, A. G.: Standard potential of the reaction: $\mathrm{AgCl}(\mathrm{s})+12 \mathrm{H}_{2}(\mathrm{~g})=\mathrm{Ag}(\mathrm{s})+\mathrm{HCl}(\mathrm{aq})$ and the standard acidity constant of the ion $\mathrm{HSO}_{4}^{-}$in synthetic sea water from 273.15 to $318.15 \mathrm{~K}$, J. Chem. Thermodyn., 22, 113-127, https://doi.org/10.1016/0021-9614(90)90074-Z, 1990.

Dinauer, A. and Mucci, A.: Spatial variability in surface-water $p \mathrm{CO}_{2}$ and gas exchange in the world's largest semi-enclosed estuarine system: St. Lawrence Estuary (Canada), Biogeosciences, 14, 3221-3237, https://doi.org/10.5194/bg-14-3221-2017, 2017.

Doney, S. C., Fabry, V. J., Feely, R. A., and Kleypas, J. A.: Ocean acidification: The other $\mathrm{CO}_{2}$ problem, Annu. Rev. Mar. Sci., 1, 169-192, https://doi.org/10.1146/annurev.marine.010908.163834, 2009.

Duarte, C. M., Hendriks, I. E., Moore, T. S., Olsen, Y. S., Steckbauer, A., Ramajo, L., Carstensen, J., Trotter, J. A., and McCulloch, M.: Is ocean acidification an open-ocean syndrome? Understanding anthropogenic impacts on seawater $\mathrm{pH}$, Estuaries Coasts, 36, 221-236, https://doi.org/10.1007/s12237-013-9594$3,2013$.

Eberlein, T., Wohlrab, S., Rost, B., John, U., Bach, L. T., Riebesell, U., and Van De Waal, D. B.: Effects of ocean acidification on primary production in a coastal North Sea phytoplankton community, PLoS ONE, 12, e0172594, https://doi.org/10.1371/journal.pone.0172594, 2017.

Engel, A., Zondervan, I., Aerts, K., Beaufort, L., Benthien, A., Chou, L., Delille, B., Gattuso, J.-P., Harlay, J., Heeman, C., Hoffmann, L., Jacquet, S., Nejstgaard, J., Pizay, M.D., Rochelle-Newall, E., Schneider, U., Terbrueggen A., and Riebesell, U.: Testing the direct effect of $\mathrm{CO}_{2}$ concentration on a bloom of the coccolithophorid Emiliania huxleyi in mesocosm experiments, Limnol. Oceanogr., 50, 493-507, https://doi.org/10.4319/lo.2005.50.2.0493, 2005.

Engel, A., Händel, N., Wohlers, J., Lunau, M., Grossart, H.-P., Sommer, U., and Riebesell, U.: Effects of sea surface warming on the production and composition of dissolved organic matter during phytoplankton blooms: Results from a mesocosm study, J. Plankton Res., 33, 357-372, https://doi.org/10.1093/plankt/fbq122, 2011.

Engel, A., Borchard, C., Piontek, J., Schulz, K. G., Riebesell, U., and Bellerby, R.: $\mathrm{CO}_{2}$ increases ${ }^{14} \mathrm{C}$ primary production in an Arctic plankton community, Biogeosciences, 10, 1291-1308, https://doi.org/10.5194/bg-10-1291-2013, 2013.

Engel, A., Piontek, J., Grossart, H.-P., Riebesell, U., Schulz, K. G., and Sperling, M.: Impact of $\mathrm{CO}_{2}$ enrichment on organic matter dynamics during nutrient induced coastal phytoplankton blooms, J. Plankton Res., 36, 641-657, https://doi.org/10.1093/plankt/fbt125, 2014.

Feely, R. A., Doney, S. C., and Cooley, S. R.: Ocean acidification: present conditions and future changes in a high- $\mathrm{CO}_{2}$ world, Oceanography, 22, 36-47, https://doi.org/10.5670/oceanog.2009.95, 2009.

Feng, Y., Hare, C. E., Leblanc, K., Rose, J. M., Zhang, Y., DiTullio, G. R., Lee, P. A., Wilhelm, S. W., Rowe, J. M., Sun, J., Nemcek, N., Gueguen, C., Passow, U., Benner, I., Brown, C., and Hutchins, D. A.: Effects of increased $p \mathrm{CO}_{2}$ and temperature on the North Atlantic spring bloom. I. The phytoplankton community and biogeochemical response, Mar. Ecol.-Prog. Ser., 388, 13-25, https://doi.org/10.3354/meps08133, 2009.

Ferland, J., Gosselin, M., and Starr, M.: Environmental control of summer primary production in the Hudson Bay system: The role of stratification, J. Marine Syst., 88, 385-400, https://doi.org/10.1016/j.jmarsys.2011.03.015, 2011.

Fu, F. X., Warner, M. E., Zhang, Y., Feng, Y., and Hutchins, D. A.: Effects of increased temperature and $\mathrm{CO}_{2}$ on photosynthesis, growth, and elemental ratios in marine Synechococcus and Prochlorococcus (Cyanobacteria), J. Phycol., 43, 485-496, https://doi.org/10.1111/j.1529-8817.2007.00355.x, 2007.

Gaaloul, H.: Effets du changement global sur les particules exopolymériques transparentes au sein de l'estuaire maritime du Saint-Laurent, M.Sc. thesis, Université du Québec à Rimouski, Canada, 133 pp., 2017.

Galbraith, P. S., Chassé, J., Gilbert, D., Larouche, P., Caverhill, C., Lefaivre, D., Brickman, D., Pettigrew, B., Devine, L., and Lafleur, C.: Physical Oceanographic Conditions in the Gulf of St. Lawrence in 2013, DFO Can. Sci. Advis. Sec. Res. Doc., 2014/062 (November), vi + 84 pp., 2014.

Gao, G., Jin, P., Liu, N., Li, F., Tong, S., Hutchins, D. A., and Gao, K.: The acclimation process of phytoplankton biomass, carbon fixation and respiration to the combined effects of elevated temperature and $\mathrm{pCO}_{2}$ in the north- 
ern South China Sea, Mar. Pollut. Bull., 118, 213-220, https://doi.org/10.1016/j.marpolbul.2017.02.063, 2017.

Gao, K. and Campbell, D. A.: Photophysiological responses of marine diatoms to elevated $\mathrm{CO}_{2}$ and decreased $\mathrm{pH}$ : A review, Funct. Plant Biol., 41, 449-459, https://doi.org/10.1071/FP13247, 2014

Gattuso, J. P., Mach, K. J., and Morgan, G.: Ocean acidification and its impacts: An expert survey, Climatic Change, 117, 725-738, https://doi.org/10.1007/s10584-012-0591-5, 2013.

Gattuso, J.-P., Magnan, A., Bille, R., Cheung, W. W. L., Howes, E. L., Joos, F., Allemand, D., Bopp, L., Cooley, S. R., Eakin, C. M., Hoegh-Guldberg, O., Kelly, R. P., Portner, H.-O., Rogers, A. D., Baxter, J. M., Laffoley, D., Osborn, D., Rankovic, A., Rochette, J., Sumaila, U. R., Treyer, S., and Turley, C.: Contrasting futures for ocean and society from different anthropogenic $\mathrm{CO}_{2}$ emissions scenarios, Science, 349, aac4722, https://doi.org/10.1126/science.aac4722, 2015.

Giordano, M., Beardall, J., and Raven, J. A.: $\mathrm{CO}_{2}$ concentrating mechanisms in algae: Mechanisms, environmental modulation., and evolution, Annu. Rev. Plant Biol., 56, 99131, https://doi.org/10.1146/annurev.arplant.56.032604.144052, 2005.

Gunderson, A. R., Armstrong, E. J., and Stillman, J. H.: Multiple stressors in a changing World: The need for an improved perspective on physiological responses to the dynamic marine environment, Annu. Rev. Mar. Sci., 8, 357-378, https://doi.org/10.1146/annurev-marine-122414-033953, 2016.

Hama, T., Inoue, T., Suzuki, R., Kashiwazaki, H., Wada, S., Sasano, D., Kosugi, N., and Ishii, M.: Response of a phytoplankton community to nutrient addition under different $\mathrm{CO}_{2}$ and $\mathrm{pH}$ conditions, J. Oceanogr., 72, 207-223, https://doi.org/10.1007/s10872-015-0322-4, 2016.

Hansen, H. P. and Koroleff, F.: Determination of nutrients, in: Methods of Seawater Analysis, 3, edited by: Grasshoff K., Kremling, K., and Ehrhardt, M., WileyVCH Verlag GmbH, Weinheim, Germany, 159-228, https://doi.org/10.1002/9783527613984.ch10, 2007.

Hare, C. E., Leblanc, K., DiTullio, G. R., Kudela, R. M., Zhang, Y., Lee, P. A., Riseman, S., and Hutchins, D. A.: Consequences of increased temperature and $\mathrm{CO}_{2}$ for phytoplankton community structure in the Bering Sea, Mar. Ecol.-Prog. Ser., 352, 9-16, https://doi.org/10.3354/meps07182, 2007.

Havenhand, J., Dupont, S., and Quinn, G. P.: Designing ocean acidification experiments to maximise inference, in: Guide to best practices for ocean acidification research and data reporting, edited by: Riebesell, U., Fabry, V. J., and Gattuso, J.-P., Publications Office of the European Union, Luxembourg, 67-80, 2010.

Hopkins, F. E., Turner, S. M., Nightingale, P. D., Steinke, M., Bakker, D., and Liss, P. S.: Ocean acidification and marine trace gas emissions, P. Natl. Acad. Sci. USA, 107, 760-765, https://doi.org/10.1073/pnas.0907163107, 2010.

Hussherr, R., Levasseur, M., Lizotte, M., Tremblay, J.-É., Mol, J., Thomas, H., Gosselin, M., Starr, M., Miller, L. A., Jarniková, T., Schuback, N., and Mucci, A.: Impact of ocean acidification on Arctic phytoplankton blooms and dimethyl sulfide concentration under simulated ice-free and under-ice conditions, Biogeosciences, 14, 2407-2427, https://doi.org/10.5194/bg-142407-2017, 2017.
IPCC: Working Group I Contribution to the Fifth Assessment Report Climate Change 2013: The Physical Science Basis, Intergov. Panel Clim. Chang., 1535, Cambridge University Press, Cambridge, UK, https://doi.org/10.1017/CBO9781107415324, 2013.

Kim, J.-H., Kim, K. Y., Kang, E. J., Lee, K., Kim, J.-M., Park, K.-T., Shin, K., Hyun, B., and Jeong, H. J.: Enhancement of photosynthetic carbon assimilation efficiency by phytoplankton in the future coastal ocean, Biogeosciences, 10, 7525-7535, https://doi.org/10.5194/bg-10-7525-2013, 2013.

Kim, J. M., Lee, K., Shin, K., Yang, E. J., Engel, A., Karl, D. M., and Kim, H. C.: Shifts in biogenic carbon flow from particulate to dissolved forms under high carbon dioxide and warm ocean conditions, Geophys. Res. Lett., 38, L08612, https://doi.org/10.1029/2011GL047346, 2011.

Kim, K. Y., Garbary, D. J., and Mclachlan, J. L.: Phytoplankton dynamics in Pomquet Harbour, Nova Scotia: a lagoon in the southern Gulf of St Lawrence, Phycologica, 43, 311-328, 2004.

Knap, A., Michaels, A., Close, A. R., Ducklow, H., and Dickson, A. G.: Protocols for the Joint Global Ocean Flux Study (JGOFS) core measurements, JGOFS Rep No. 19, Reprint of the IOC Manuals and Guides No. 29, UNESCO, Bergen, Norway, 1996.

Kroeker, K. J., Kordas, R. L., Crim, R., Hendriks, I. E., Ramajo, L., Singh, G. S., Duarte, C. M., and Gattuso, J. P.: Impacts of ocean acidification on marine organisms: Quantifying sensitivities and interaction with warming, Glob. Change Biol., 19, 1884-1896, https://doi.org/10.1111/gcb.12179, 2013.

Larouche, P. and Galbraith, P. S.: Canadian coastal seas and Great Lakes sea surface temperature climatology and recent trends, Can. J. Remote Sens., 42, 243-258, https://doi.org/10.1080/07038992.2016.1166041, 2016.

Law, C. S., Breitbarth, E., Hoffmann, L. J., McGraw, C. M., Langlois, R. J., Laroche, J., Marriner, A., and Safi, K. A.: No stimulation of nitrogen fixation by non-filamentous diazoytrophs under elevated $\mathrm{CO}_{2}$ in the South Pacific, Glob. Change Biol., 18, 3004-3014, 2012.

Legendre, L., Demers, S., Yentsch, C. M., and Yentsch, C. S.: The ${ }^{14} \mathrm{C}$ method: Patterns of dark $\mathrm{CO}_{2}$ fixation and DCMU correction to replace the dark bottle, Limnol. Oceanogr., 28, 996-1003, https://doi.org/10.4319/lo.1983.28.5.0996, 1983.

Le Quéré, C., Moriarty, R., Andrew, R. M., Canadell, J. G., Sitch, S., Korsbakken, J. I., Friedlingstein, P., Peters, G. P., Andres, R. J., Boden, T. A., Houghton, R. A., House, J. I., Keeling, R. F., Tans, P., Arneth, A., Bakker, D. C. E., Barbero, L., Bopp, L., Chang, J., Chevallier, F., Chini, L. P., Ciais, P., Fader, M., Feely, R. A., Gkritzalis, T., Harris, I., Hauck, J., Ilyina, T., Jain, A. K., Kato, E., Kitidis, V., Klein Goldewijk, K., Koven, C., Landschützer, P., Lauvset, S. K., Lefèvre, N., Lenton, A., Lima, I. D., Metzl, N., Millero, F., Munro, D. R., Murata, A., Nabel, J. E. M. S., Nakaoka, S., Nojiri, Y., O’Brien, K., Olsen, A., Ono, T., Pérez, F. F., Pfeil, B., Pierrot, D., Poulter, B., Rehder, G., Rödenbeck, C., Saito, S., Schuster, U., Schwinger, J., Séférian, R., Steinhoff, T., Stocker, B. D., Sutton, A. J., Takahashi, T., Tilbrook, B., van der Laan-Luijkx, I. T., van der Werf, G. R., van Heuven, S., Vandemark, D., Viovy, N., Wiltshire, A., Zaehle, S., and Zeng, N.: Global Carbon Budget 2015, Earth Syst. Sci. Data, 7, 349-396, https://doi.org/10.5194/essd-7-349-2015, 2015.

Levasseur, M., Therriault, J.-C., and Legendre, L.: Hierarchical control of phytoplankton succession by physical factors, Mar. Ecol.- 
Prog. Ser., 19, 211-222, https://doi.org/10.3354/meps019211, 1984.

Levasseur, M. E. and Therriault, J.-C.: Phytoplankton biomass and nutrient dynamics in a tidally induced upwelling: the role of teh $\mathrm{NO}_{3}: \mathrm{SiO}_{4}$ ratio, Mar. Ecol.-Prog. Ser., 39, 87-97, 1987.

Levasseur, M. E., Harrison, P. J., Heimdal, B. R., and Therriault, J.-C.: Simultaneous nitrogen and silicate deficiency of a phytoplankton community in a coastal jet-front, Mar. Biol., 104, 329338, https://doi.org/10.1007/BF01313275, 1990.

Lomas, M. W., Hopkinson, B. M., Losh, J. L., Ryan, D. E., Shi, D. L., Xu, Y., and Morel, F. M. M.: Effect of ocean acidification on cyanobacteria in the subtropical North Atlantic, Aquat. Microb. Ecol., 66, 211-222, https://doi.org/10.3354/ame01576, 2012.

Lund, J. W. G., Kipling, C., and Le Cren, E. D.: The inverted microscope method of estimating algal numbers and the statistical basis of estimates by counting, Hydrobiologia, 11, 143-170, 1958.

MacGilchrist, G. A., Shi, T., Tyrrell, T., Richier, S., Moore, C. M., Dumousseaud, C., and Achterberg, E. P.: Effect of enhanced $p \mathrm{CO}_{2}$ levels on the production of dissolved organic carbon and transparent exopolymer particles in shortterm bioassay experiments, Biogeosciences, 11, 3695-3706, https://doi.org/10.5194/bg-11-3695-2014, 2014.

Marie, D., Simon, N., and Vaulot, D.: Phytoplankton cell counting by flow cytometry, in: Algal culturing techniques, edited by: Andersen, R. A., Elsevier Academic Press, San Diego, USA, 253267, 2005.

Maugendre, L., Gattuso, J. P., Louis, J., De Kluijver, A., Marro, S., Soetaert, K., and Gazeau, F.: Effect of ocean warming and acidification on a plankton community in the NW Mediterranean Sea, ICES J. Mar. Sci., 72, 1744-1755, https://doi.org/10.1093/icesjms/fsu161, 2015.

Millero, F. J.: The pH of estuarine waters, Limnol. Oceanogr., 31, 839-847, https://doi.org/10.4319/lo.1986.31.4.0839, 1986.

Montagnes, D. J. S. and Franklin, M.: Effect of temperature on diatom volume, growth rate, and carbon and nitrogen content: Reconsidering some paradigms, Limnol. Oceanogr., 46, 20082018, https://doi.org/10.4319/lo.2001.46.8.2008, 2001.

Morán, X. A. G., Alonso-Sáez, L., Nogueira, E., Ducklow, H. W., González, N., López-Urrutia, Á, Díaz-Pérez, L., Calvo-Díaz, A., Arandia-Gorostidi, N., and Huete-Stauffer, T. M.: More, smaller bacteria in response to ocean's warming?, P. R. Soc B, 282, 1-9, https://doi.org/10.1098/rspb.2015.0371, 2015.

Morán, X. A. G., Sebastián, M., Pedrós-Alió, C., and Estrada, M.: Response of Southern Ocean phytoplankton and bacterioplankton production to short-term experimental warming, Limnol. Oceanogr., 51, 1791-1800, https://doi.org/10.4319/lo.2006.51.4.1791, 2006.

Mucci, A., Levasseur, M., Gratton, Y., Martias, C., Scarratt, M., Gilbert, D., Tremblay, J.-É., Ferreyra, G., and Lansard, B.: Tidally-induced variations of $\mathrm{pH}$ at the head of the Laurentian Channel, Can. J. Fish. Aquat. Sci., 75, 1128-1141, https://doi.org/10.1139/cjfas-2017-0007, 2018.

Neale, P. J., Sobrino, C., Segovia, M., Mercado, J. M., Leon, P., Cortés, M. D., Tuite, P., Picazo, A., Salles, S., Cabrerizo, M. J., Prasil, O., Montecino, V., and Reul, A.: Effect of $\mathrm{CO}_{2}$, nutrients and light on coastal plankton. I. Abiotic conditions and biological responses, Aquat. Biol., 22, 25-41, https://doi.org/10.3354/ab00587, 2014.
Parsons, T. R., Maita, Y., and Lalli, C. M.: A manual of chemical and biological methods for seawater analysis, Permagon Press, New York, 1984.

Paul, C., Matthiessen, B., and Sommer, U.: Warming, but not enhanced $\mathrm{CO}_{2}$ concentration, quantitatively and qualitatively affects phytoplankton biomass, Mar. Ecol.-Prog. Ser., 528, 39-51, https://doi.org/10.3354/meps11264, 2015.

Paul, C., Sommer, U., Garzke, J., Moustaka-Gouni, M., Paul, A., and Matthiessen, B.: Effects of increased $\mathrm{CO}_{2}$ concentration on nutrient limited coastal summer plankton depend on temperature, Limnol. Oceanogr., 61, 853-868, https://doi.org/10.1002/lno.10256, 2016.

Paulino, A. I., Egge, J. K., and Larsen, A.: Effects of increased atmospheric $\mathrm{CO}_{2}$ on small and intermediate sized osmotrophs during a nutrient induced phytoplankton bloom, Biogeosciences, 5, 739-748, https://doi.org/10.5194/bg-5-739-2008, 2008.

Pierrot, D., Lewis, E., and Wallace, D. W. R.: MS Excel program developed for $\mathrm{CO}_{2}$ system calculations, Carbon Dioxide Information Analysis Center, ORNL/CDIAC-105a, Oak Ridge National Laboratory, US Department of Energy, Oak Ridge, 592 Tennessee, 2006.

Raven, J. A., Beardall, J., and Giordano, M.: Energy costs of carbon dioxide concentrating mechanisms in aquatic organisms, Photosynth. Res., 121, 111-124, 2014.

Riebesell, U. and Gattuso, J.-P.: Lessons learned from ocean acidification research, Nat. Clim. Change, 5, 12-14, https://doi.org/10.1038/nclimate2456, 2015.

Riebesell, U. and Tortell, P. D.: Effects of ocean acidification on pelagic organism and ecosystems, in: Ocean Acidification, edited by: Gattuso, J.-P. and Hansson L., Oxford University Press, New York, 99-121, 2011.

Riebesell, U., Schulz, K. G., Bellerby, R. G. J., Botros, M., Fritsche, P., Meyerhöfer, M., Neill, C., Nondal, G., Oschlies, A., Wohlers, J., and Zöllner, E.: Enhanced biological carbon consumption in a high $\mathrm{CO}_{2}$ ocean, Nature, 450, 545-548, https://doi.org/10.1038/nature06267, 2007.

Riebesell, U., Czerny, J., von Bröckel, K., Boxhammer, T., Büdenbender, J., Deckelnick, M., Fischer, M., Hoffmann, D., Krug, S. A., Lentz, U., Ludwig, A., Muche, R., and Schulz, K. G.: Technical Note: A mobile sea-going mesocosm system - new opportunities for ocean change research, Biogeosciences, 10, 18351847, https://doi.org/10.5194/bg-10-1835-2013, 2013.

Robarts, R. D. and Zohary, T.: Temperature effects on photosynthetic capacity, respiration., and growth rates of bloomforming cyanobacteria, New Zeal. J. Mar. Fresh., 21, 391-399, https://doi.org/10.1080/00288330.1987.9516235, 1987.

Robert-Baldo, G., Morris, M., and Byrne, R.: Spectrophotometric determination of seawater $\mathrm{pH}$ using phenol red, Anal. Chem., 3, 2564-2567, https://doi.org/10.1021/ac00290a030, 1985.

Rose, J. M., Feng, Y., Gobler, C. J., Gutierrez, R., Harel, C. E., Leblanc, K., and Hutchins, D. A.: Effects of increased $p \mathrm{CO}_{2}$ and temperature on the North Atlantic spring bloom. II. Microzooplankton abundance and grazing, Mar. Ecol.-Prog. Ser., 388, 27-40, https://doi.org/10.3354/meps08134, 2009.

Roy, S., Chanut, J.-P., Gosselin, M., and Sime-Ngando, T.: Characterization of phytoplankton communities in the Lower St. Lawrence Estuary using HPLC-detected pigments and cell microscopy, Mar. Ecol.-Prog. Ser., 142, 55-73, https://doi.org/10.3354/meps142055, 1996. 
Sala, M. M., Aparicio, F. L., Balagué, V., Boras, J. A., Borrull, E., Cardelús, C., Cros, L., Gomes, A., López-Sanz, A., Malits, A., Martinez, R. A., Mestre, M., Movilla, J., Sarmento, H., Vázquez-Domínguez, E., Vaqué, D., Pinhassi, J., Calbet, A., Calvo, E., Gasol, J. M., Pelejero, C., and Marrasé, C.: Contrasting effects of ocean acidification on the microbial food web under different trophic conditions, ICES J. Mar. Sci., 73, 670-679, https://doi.org/10.1093/icesjms/fsv130, 2016.

Schulz, K. G., Bellerby, R. G. J., Brussaard, C. P. D., Büdenbender, J., Czerny, J., Engel, A., Fischer, M., Koch-Klavsen, S., Krug, S. A., Lischka, S., Ludwig, A., Meyerhöfer, M., Nondal, G., Silyakova, A., Stuhr, A., and Riebesell, U.: Temporal biomass dynamics of an Arctic plankton bloom in response to increasing levels of atmospheric carbon dioxide, Biogeosciences, 10, 161180, https://doi.org/10.5194/bg-10-161-2013, 2013.

Schulz, K. G., Bach, L. T., Bellerby, R. G. J., Bermudez, R., Budenbender, J., Boxhammer, T., Czerny, J., Engel, A., Ludwig, A., Meyerhofer, M., Larsen, A., Paul, A., Sswat, M., and Riebesell, U.: Phytoplankton blooms at increasing levels of atmospheric carbon dioxide: experimental evidence for negative effects on prymnesiophytes and positive on small picoeukaryotes, Front. Mar. Sci., 4, 64, https://doi.org/10.3389/fmars.2017.00064, 2017.

Sommer, U. and Lengfellner, K.: Climate change and the timing, magnitude, and composition of the phytoplankton spring bloom, Glob. Change Biol., 14, 1199-1208, https://doi.org/10.1111/j.1365-2486.2008.01571.x, 2008.

Sommer, U., Paul, C., and Moustaka-Gouni, M.: Warming and ocean acidification effects on phytoplankton - From species shifts to size shifts within species in a mesocosm experiment, PLoS ONE, 10, 17, https://doi.org/10.1371/journal.pone.0125239, 2015.

Starr, M., St-Amand, L., Devine, L., Bérard-Therriault, L., and Galbraith, P. S.: State of phytoplankton in the Estuary and Gulf of St. Lawrence during 2003, DFO Can. Sci. Advis. Sec. Res. Doc., 2004/123, ii+31 pp., 2004.

Suzuki, Y. and Takahashi, M.: Growth responses of several diatom species isolated from various environments to temperature, J. Phycol., 31, 880-888, https://doi.org/10.1111/j.00223646.1995.00880.x, 1995.

Tatters, A. O., Roleda, M. Y., Schnetzer, A., Fu, F., Hurd, C. L., Boyd, P. W., Caron, D. A., Lie, A. A. Y., Hoffmann, L. J., and Hutchins, D. A.: Short- and long-term conditioning of a temperate marine diatom community to acidification and warming, Philos. T. Roy. Soc. B, 368, 20120437 , https://doi.org/10.1098/rstb.2012.0437, 2013.

Taylor, A. H., Harbour, D. S., Harris, R. P., Burkill, P. H., and Edwards, E. S.: Seasonal succession in the pelagic ecosystem of the North Atlantic and the utilization of nitrogen, J. Plankton Res., 15, 875-891, https://doi.org/10.1093/plankt/15.8.875, 1993.
Thomas, M. K., Kremer, C. T., Klausmeier, C. A., and Litchman, E.: A global pattern of thermal adaptation in marine phytoplankton, Science, 338, 1085-1088, https://doi.org/10.1126/science.1224836, 2012.

Todgham, A. E. and Stillman, J. H.: Physiological responses to shifts in multiple environmental stressors: Relevance in a changing world, Integr. Comp. Biol., 53, 539-544, https://doi.org/10.1093/icb/ict086, 2013.

Tomas, C. R. (Ed.): Identifying Marine Phytoplankton, Academic Press, San Diego, 858 pp., 1997.

Tortell, P. D., DiTullio, G. R., Sigman, D. M., and Morel, F. M. M.: $\mathrm{CO}_{2}$ effects on taxonomic composition and nutrient utilization in an Equatorial Pacific phytoplankton assemblage, Mar. Ecol.Prog. Ser., 236, 37-43, https://doi.org/10.3354/meps236037, 2002.

Trimborn, S., Wolf-Gladrow, D., Richter, K. U., and Rost, B.: The effect of $p \mathrm{CO}_{2}$ on carbon acquisition and intracellular assimilation in four marine diatoms, J. Exp. Mar. Bio. Ecol., 376, 26-36, https://doi.org/10.1016/j.jembe.2009.05.017, 2009.

Wijffels, S., Roemmich, D., Monselesan, D., Church, J., and Gilson, J.: Ocean temperatures chronicle the ongoing warming of Earth, Nat. Clim. Change, 6, 116-118, https://doi.org/10.1038/nclimate2924, 2016.

Wohlers, J., Engel, A., Zollner, E., Breithaupt, P., Jurgens, K., Hoppe, H.-G., Sommer, U., and Riebesell, U.: Changes in biogenic carbon flow in response to sea surface warming, P. Natl. Acad. Sci. USA, 106, 7067-7072, https://doi.org/10.1073/pnas.0812743106, 2009.

Wu, Y., Gao, K., and Riebesell, U.: $\mathrm{CO}_{2}$-induced seawater acidification affects physiological performance of the marine diatom Phaeodactylum tricornutum, Biogeosciences, 7, 29152923, https://doi.org/10.5194/bg-7-2915-2010, 2010.

Yoshimura, T., Nishioka, J., Suzuki, K., Hattori, H., Kiyosawa, H., and Watanabe, Y. W.: Impacts of elevated $\mathrm{CO}_{2}$ on organic carbon dynamics in nutrient depleted Okhotsk Sea surface waters, J. Exp. Mar. Bio. Ecol., 395, 191-198, https://doi.org/10.1016/j.jembe.2010.09.001, 2010.

Yoshimura, T., Sugie, K., Endo, H., Suzuki, K., Nishioka, J., and Ono, T.: Organic matter production response to $\mathrm{CO}_{2}$ increase in open subarctic plankton communities: Comparison of six microcosm experiments under iron-limited and enriched bloom conditions, Deep-Sea Res. Pt. I, 94, 1-14, https://doi.org/10.1016/j.dsr.2014.08.004, 2014. 